\title{
Tracing glacier changes since the 1960s on the south slope of Mt. Everest (central Southern Himalaya) using optical satellite imagery
}

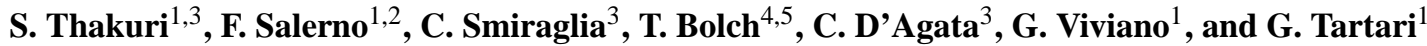 \\ ${ }^{1}$ National Research Council, Water Research Institute (IRSA-CNR), Brugherio, Italy \\ ${ }^{2}$ Ev-K2-CNR Committee, Via San Bernardino, 145, Bergamo 24126, Italy \\ ${ }^{3}$ Department of Earth Sciences "Ardito Desio", University of Milan, Milan, Italy \\ ${ }^{4}$ Department of Geography, University of Zurich, Zurich, Switzerland \\ ${ }^{5}$ Institute for Cartography, Technische Universität Dresden, Dresden, Germany
}

Correspondence to: S. Thakuri (thakuri@irsa.cnr.it)

Received: 1 September 2013 - Published in The Cryosphere Discuss.: 8 November 2013

Revised: 11 March 2014 - Accepted: 12 June 2014 - Published: 22 July 2014

\begin{abstract}
This contribution examines glacier changes on the south side of Mt. Everest from 1962 to 2011 considering five intermediate periods using optical satellite imagery. The investigated glaciers cover $\sim 400 \mathrm{~km}^{2}$ and present among the largest debris coverage (32\%) and the highest elevations $(5720 \mathrm{~m})$ of the world. We found an overall surface area loss of $13.0 \pm 3.1 \%$ (median $0.42 \pm 0.06 \% \mathrm{a}^{-1}$ ), an upward shift of $182 \pm 22 \mathrm{~m}\left(3.7 \pm 0.5 \mathrm{~m} \mathrm{a}^{-1}\right)$ in snowline altitude (SLA), a terminus retreat of $403 \pm 9 \mathrm{~m}$ (median $6.1 \pm 0.2 \mathrm{~m} \mathrm{a}^{-1}$ ), and an increase of $17.6 \pm 3.1 \%$ (median $\left.0.20 \pm 0.06 \% \mathrm{a}^{-1}\right)$ in debris coverage between 1962 and 2011. The recession process of glaciers has been relentlessly continuous over the past 50 years. Moreover, we observed that (i) glaciers that have increased the debris coverage have experienced a reduced termini retreat $(r=0.87, p<0.001)$. Furthermore, more negative mass balances (i.e., upward shift of SLA) induce increases of debris coverage ( $r=0.79$, $p<0.001$ ); (ii) since early 1990s, we observed a slight but statistically insignificant acceleration of the surface area loss $\left(0.35 \pm 0.13 \% \mathrm{a}^{-1}\right.$ in $1962-1992$ vs $0.43 \pm 0.25 \% \mathrm{a}^{-1}$ in 1992-2011), but an significant upward shift of SLA which increased almost three times $\left(2.2 \pm 0.8 \mathrm{~m} \mathrm{a}^{-1}\right.$ in $1962-1992$ vs $6.1 \pm 1.4 \mathrm{~m} \mathrm{a}^{-1}$ in 1992-2011). However, the accelerated shrinkage in recent decades (both in terms of surface area loss and SLA shift) has only significantly affected glaciers with the largest sizes $\left(>10 \mathrm{~km}^{2}\right)$, presenting accumulation zones at higher elevations $(r=0.61, p<0.001)$ and along
\end{abstract}

the preferable south-north direction of the monsoons. Moreover, the largest glaciers present median upward shifts of the SLA $(220 \mathrm{~m})$ that are nearly double than that of the smallest $(119 \mathrm{~m})$; this finding leads to a hypothesis that Mt. Everest glaciers are shrinking, not only due to warming temperatures, but also as a result of weakening Asian monsoons registered over the last few decades. We conclude that the shrinkage of the glaciers in south of Mt. Everest is less than that of others in the western and eastern Himalaya and southern and eastern Tibetan Plateau. Their position in higher elevations have likely reduced the impact of warming on these glaciers, but have not been excluded from a relentlessly continuous and slow recession process over the past 50 years.

\section{Introduction}

The controversies concerning the possibly faster glacial shrinkage in the Himalaya than in any other part of the world (Cogley et al., 2010; Bagla, 2009) have focused global attention on necessity for a more comprehensive study in this region. Current uncertainties are mainly attributed to a lack of measurements, both of glaciers and of climatic forcing agents (Bolch et al., 2012). The need for a fine-scale investigation is particularly evident on the south slope of Mt. Everest, which is one of the most heavily glacierized parts of the Himalaya. Glaciers here are characterized by abundant debris coverage 


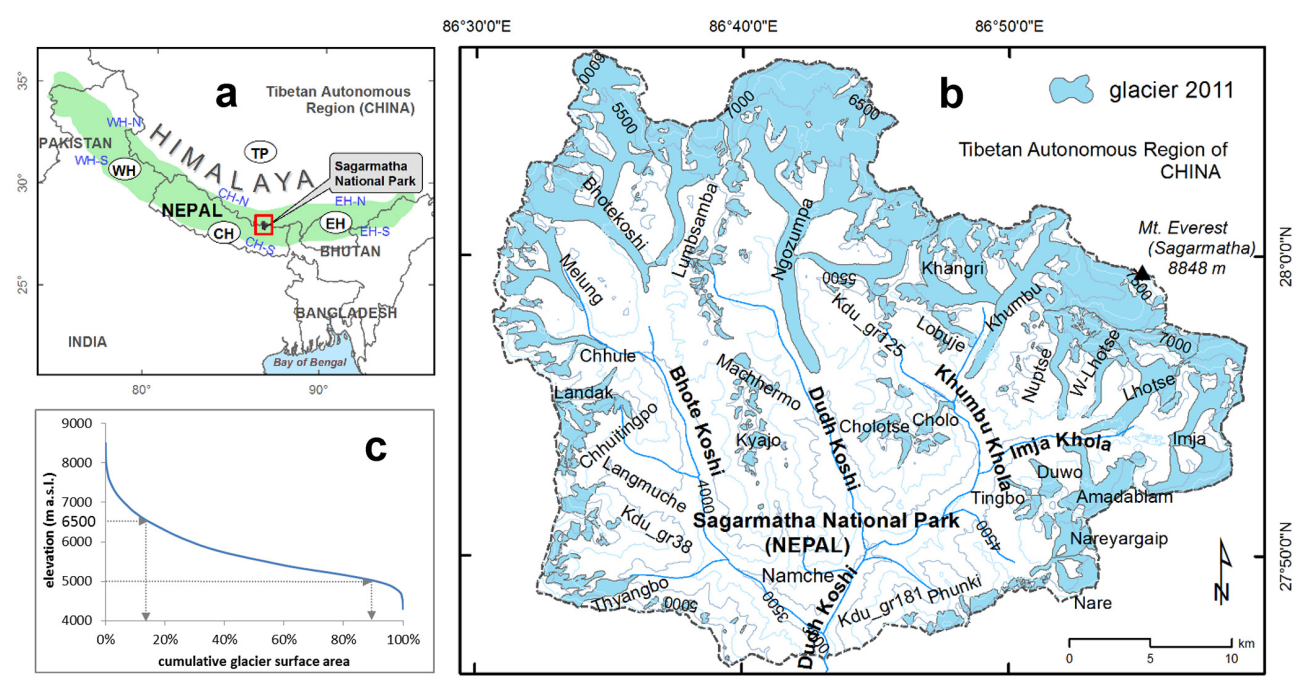

Figure 1. (a) Location of the study area: the Sagarmatha National Park (SNP), where the abbreviations CH, WH, EH, and TP represent the central Himalaya, the western Himalaya, the eastern Himalaya, and the Tibetan Plateau, respectively (suffixes -N and -S indicate the northern and southern slopes). (b) Focused map of the SNP in 2011 showing the distribution of 29 glaciers considered in this study with a surface area $>1 \mathrm{~km}^{2}$. (c) The hypsometric curve of the glaciers in 2011 .

(Scherler et al., 2011; Salerno et al., 2012), an effect that has often been neglected in predictions of future water availability.

Some previous studies have discussed that debris-covered glaciers behave unlike clean glaciers (Nakawo et al., 1999; Benn et al., 2012). Scherler et al. (2011) studied debriscovered glaciers around the Himalayan range for a period of 2000-2008 and showed that heavy debris coverage influences terminus behaviors by stabilizing the terminus position change. However, Kääb et al. (2012), in a comprehensive study on the glacier mass change from 2003-2008 in the Himalaya, suggested that debris-covered ice thins at a rate similar to that of exposed ice. Significant mass loss despite thick debris cover was also reported by Bolch et al. (2011), Nuimura et al. (2012), and Pieczonka et al. (2013). Hence, the relation of length changes to mass balance is even weaker for debris-covered than for debris-free glaciers and there is a need for further assessment of the role of debris mantles.

This contribution examines the glacier changes on the south side of Mt. Everest as part of an effort to better define the glaciers status in the Himalaya. We extend the analysis of Salerno et al. (2008) carried out on the glacier surface area change ( $\Delta$ Surf) on two historical maps (the period ranging from the 1950s to 1992). First of all, we cover a longer period (ranging from the 1960s to 2011) increasing furthermore the temporal resolution with six medium-high resolution satellite imagery, with the assistance of all available historical maps. Secondly, we make a complete analysis of terminus position change $(\Delta$ Term $)$, shift of snow-line altitude $(\Delta$ SLA), and changes in debris coverage ( $\triangle$ DebrisCov). The results are compared with those obtained in previous studies in this area and along the Himalaya and the Tibetan Plateau range. We conclude by attempting to link the observed impacts with the climate change drivers.

\section{Study area}

The current study is focused on the Mt. Everest region, and in particular in the Sagarmatha (Mt. Everest) National Park (SNP) $\left(27.75^{\circ}\right.$ to $28.11^{\circ} \mathrm{N} ; 85.98^{\circ}$ to $\left.86.51^{\circ} \mathrm{E}\right)$ that lies in eastern Nepal in the southern part of the central Himalaya (CH-S) (Fig. 1a). The park area $\left(1148 \mathrm{~km}^{2}\right)$, extending from an elevation of $2845 \mathrm{~m}$ at Jorsale to $8848 \mathrm{~m}$ a.s.l., covers the upper catchment of the Dudh Koshi river (Manfredi et al., 2010; Amatya et al., 2010). Land cover classification shows that less than $10 \%$ of the park area is forested (Salerno et al., 2010a; Bajracharya et al., 2010). The SNP is the world's highest protected area with over 30000 tourists in 2008 (Salerno et al., 2010b, 2013). This region is one of the heavily glacierized parts of the Himalaya with almost one-third of the park territory characterized by ice cover. Bajracharya and Mool (2009) indicate that there are 278 glaciers in the Dudh Koshi Basin, with 40 glaciers accounting for most of the glacierized area $(70 \%)$ and all of these being valleytype. Most of the large glaciers are debris-covered type, with their ablation zone almost entirely covered by surface debris (Fig. 1b).

Several debris-covered glaciers have stagnant ice at their termini that have potential to develop widespread melting ponds and build up moraine-dammed lakes (Bolch et al., 2008b; Quincey et al., 2009). Gardelle et al. (2011) note that the southern side of Mt. Everest is the region that is most characterized by glacial lakes in the Hindu Kush Himalaya. Salerno et al. (2012) reported a total of 624 lakes in the 
park including 17 proglacial lakes, 437 supraglacial lakes, and 170 unconnected lakes. In general, they observed that supraglacial lakes occupy from approximately 0.3 to $2 \%$ of downstream glacier surfaces.

The glacier hypsometric curve plotted, using the glacier outlines of 2011 and the Advanced Spaceborne Thermal Emission and Reflection Radiometer Global Digital Elevation Model (ASTER GDEM, a product of METI and NASA), Version 2 indicates that the glacier surfaces are distributed from around $4300 \mathrm{~m}$ to above $8000 \mathrm{~m}$ a.s.l. with more than $75 \%$ glacier surfaces lying between $5000 \mathrm{~m}$ and $6500 \mathrm{~m}$ a.s.l. (Fig. 1c); the area-weighted mean elevation of the glacier is $5720 \mathrm{~m}$ a.s. 1 in 2011. These glaciers are identified as summer-accumulation type fed mainly by summer precipitation from the South Asian monsoon system, whereas the winter precipitation caused by mid-latitude westerly wind is minimal (Ageta and Fujita, 1996; Tartari et al., 2002). The prevailing direction of the monsoons is $\mathrm{S}-\mathrm{N}$ and SWNE (Rao, 1976; Ichiyanagi et al., 2007). Based on the meteorological observations at the Pyramid Laboratory Observatory $(5050 \mathrm{~m}$ a.s.l.), the mean annual air temperature is $-2.5 \pm 0.5^{\circ} \mathrm{C}$. In summer (June-September), air temperature is typically above $0^{\circ} \mathrm{C}$, the maximum occurs in July, and shows a typical variation associated with cloudiness. In contrast, thermal range is very high during winter owing to less cloudy conditions. In winter, the maximum daily temperature is usually below $0{ }^{\circ} \mathrm{C}$, especially in February, the coldest month. Mean total annual precipitation is $516 \pm 75 \mathrm{~mm} \mathrm{a}^{-1}$, with about $88 \%$ of the annual amount recorded during the summer months (June-September). The vertical gradients of temperature, precipitation and solar radiation has been calculated using meteorological stations from 90 to 5600 m a.s.l. (data from Nepal Department of Hydrology and Meteorology - DHM - and Ev-K2-CNR Committee). We found a temperature lapse rate of $-0.0059^{\circ} \mathrm{m}^{-1}$, a solar radiation gradient of $+0.024 \mathrm{~W} \mathrm{~m}^{-2} \mathrm{~m}^{-1}$, valid for the 2800-5000 $\mathrm{m}$ a.s.l. elevation range, and for pre- and postmonsoon months, while the monsoon period is affected by high cloud cover. The precipitation increases with altitude by $+0.067 \mathrm{~mm}$ [month] $\mathrm{m}^{-1}$ until around $2800 \mathrm{~m}$ a.s.l. afterwards it starts decreasing $\left(-0.017 \mathrm{~mm}\left[\right.\right.$ month $\left.\mathrm{m}^{-1}\right)$.

\section{Data and methods}

\subsection{Data sources}

The analyses of $\Delta$ Term, $\Delta$ Surf, $\Delta$ SLA and $\Delta$ DebrisCov of Mt. Everest glaciers were performed from 1962 to 2011 using satellite imagery, with the assistance of all available historical maps (Table 1). We analyzed the glacier changes within five periods: 1962-1975, 1975-1992, 1992-2000, 2000-2008, and 2008-2011.

All satellite data were acquired after the monsoon season during the period from October-December. These images are characterized by low cloud cover and correspond to time just after the end of the snow accumulation and ablation period for that year; this allows for homogeneous comparisons (Paul et al., 2009). These months also coincides with the minimum ablation period on glaciers. The declassified Corona KH-4 (hereafter Corona-62) was used as a main data source for the base year of the analysis (1962). The Khumbu Himal map of late 1950s (Schneider, 1967; Salerno et al., 2008; hereafter KHmap-50s) and the topographic map of the Indian survey of 1963 (hereafter TISmap-63) were used to complement the results achieved using Corona-62 since the Corona-62 had the complex image geometry and absence of satellite camera specification for its rectification. The KHmap-50s has clear glacier boundaries, but the TISmap-63 has less discernible glacier outlines; thus, the first map was used for analysis related to $\Delta$ Surf, $\Delta$ Term, and $\Delta$ SLA, while use of the TISmap63 was limited to $\Delta$ Term. The Corona KH-4B (Corona-70) image covers only a small portion of the northeast part of the study area. Therefore, the Landsat MultiSpectral Scanner (MSS) (1975) (Landsat-75) was used as the main data source, although its pixel resolution is significantly lower. Moreover, we compared the 1992 Landsat Thematic Mapper (TM) scene (Landsat-92) with the official topographic map of Nepal from same year (OTNmap-92). Concerning the more recent years, we used Landsat ETM+ scenes from 2000 (Landsat-00), 2011 (Landsat-11), and an ALOS AVNIR-2 scene (ALOS-08).

The ASTER GDEM, vers. 2 tiles for the Mt. Everest region were downloaded from http://gdem.ersdac. jspacesystems.or.jp. The vertical and horizontal accuracy of the GDEM are $\sim 20 \mathrm{~m}$ and $\sim 30 \mathrm{~m}$, respectively (http://www. jspacesystems.or.jp/ersdac/GDEM/E/4.html). We decided to use the ASTER GDEM instead of the Shuttle Radar Topography Mission (SRTM) Digital Elevation Model (DEM) considering the higher resolution ( $30 \mathrm{~m}$ and $90 \mathrm{~m}$, respectively) and the large data gaps of the SRTM DEM in this study area (Bolch et al., 2011). Furthermore, the ASTER GDEM shows better performance in mountain terrains (Frey et al., 2012).

\subsection{Gap fill and pan-sharpening of Landsat SLC-off data}

The problem of the scan line corrector failure (SLC-off) gap (Parkinson et al., 2006) in Landsat-11 was corrected using the IDL (Interactive Data Language) Extension-gap fill tool in ENVI ${ }^{\circledR}$ software that uses a local linear histogram matching algorithm in the application of another image from same year (Chen et al., 2011). The effect of the SLC-off gap in our study area can be assumed to be minimal due to the central location of our study area in the Landsat scene. More than $1 / 3$ of our study area was not affected by the data gaps and the glaciers' boundaries were manually delineated taking the interpolation uncertainties into account. The Landsat11 multispectral bands $(30 \mathrm{~m})$ were pan-sharpened for visual improvement (Rodriguez-Galiano et al., 2012) using the 
Table 1. Data sources used in this study.

\begin{tabular}{|c|c|c|c|c|c|}
\hline Abbreviation used in the text & Satellite image & Acquisition date & Spatial resolution $(\mathrm{m})$ & Sensor & Scene ID \\
\hline Corona-62 & Corona & 15 Dec 1962 & $\sim 8$ & KH-4 & $\begin{array}{l}\text { DS009050054DF172_172 } \\
\text { DS009050054DA174_174 } \\
\text { DS009050054DA175_175 }\end{array}$ \\
\hline Corona-70 & Corona & 20 Nov 1970 & $\sim 5$ & $\mathrm{KH}-4 \mathrm{~B}$ & $\begin{array}{l}\text { DS1112-1023DA163_163 } \\
\text { DS1112-1023DF157_157 }\end{array}$ \\
\hline Landsat- 75 & Landsat 4 & 2 Nov 1975 & 60 & MultiSpectral Scanner (MSS) & LM21510411975306AAA05 \\
\hline Landsat-92 & Landsat 5 & 17 Nov 1992 & 30 & Thematic Mapper (TM) & ETP140R41_5T19921117 \\
\hline Landsat- 00 & Landsat 7 & 30 Oct 2000 & $15^{\mathrm{a}}$ & Enhanced Thematic Mapper Plus (ETM+) & LE71400412000304SGS00 \\
\hline ALOS-08 & Advanced Land Observation Satellite (ALOS) & 24 Oct 2008 & 10 & $\begin{array}{l}\text { Advanced Visible and Near Infrared } \\
\text { Radiometer type } 2 \text { (AVNIR-2) }\end{array}$ & ALAV2A146473040 \\
\hline Landsat-11 & Landsat 7 & 30 Nov 2011 & $15^{\mathrm{a}, \mathrm{b}}$ & ETM+ + & LE71400412011334EDC00 \\
\hline Abbreviation used in the text & Topographic map & Acquisition date & Scale & \multicolumn{2}{|l|}{ Acquisition technique } \\
\hline KHmap-50s & Khumbu Himal map (Schneider Map) & late $1950 \mathrm{~s}$ & $1: 50000$ & \multicolumn{2}{|c|}{$\begin{array}{l}\text { Photographic survey in } 1921 \text {, terrestrial } \\
\text { photogrammetric survey of } 1935 \text { and } \\
\text { 1939, field survey and terrestrial photogrammetry } \\
\text { in 1955-1963 (Schneider, 1967; Byers, 1997) }\end{array}$} \\
\hline TISmap-63 & Topographic map of Indian survey & 1963 & $1: 50000$ & \multicolumn{2}{|c|}{$\begin{array}{l}\text { Vertical aerial photographic survey 1957-1959 } \\
\text { and field survey in } 1963 \text { (Yamada, 1998) }\end{array}$} \\
\hline OTNmap-92 & Official topographic map of Nepal & 1992 & $1: 50000$ & \multicolumn{2}{|c|}{$\begin{array}{l}\text { Aerial photogrammetry (1992) and field survey (1996), } \\
\text { published in } 1997 \text { by Government of Nepal }\end{array}$} \\
\hline
\end{tabular}

a Pan-sharpened images;

b SLC-off image.
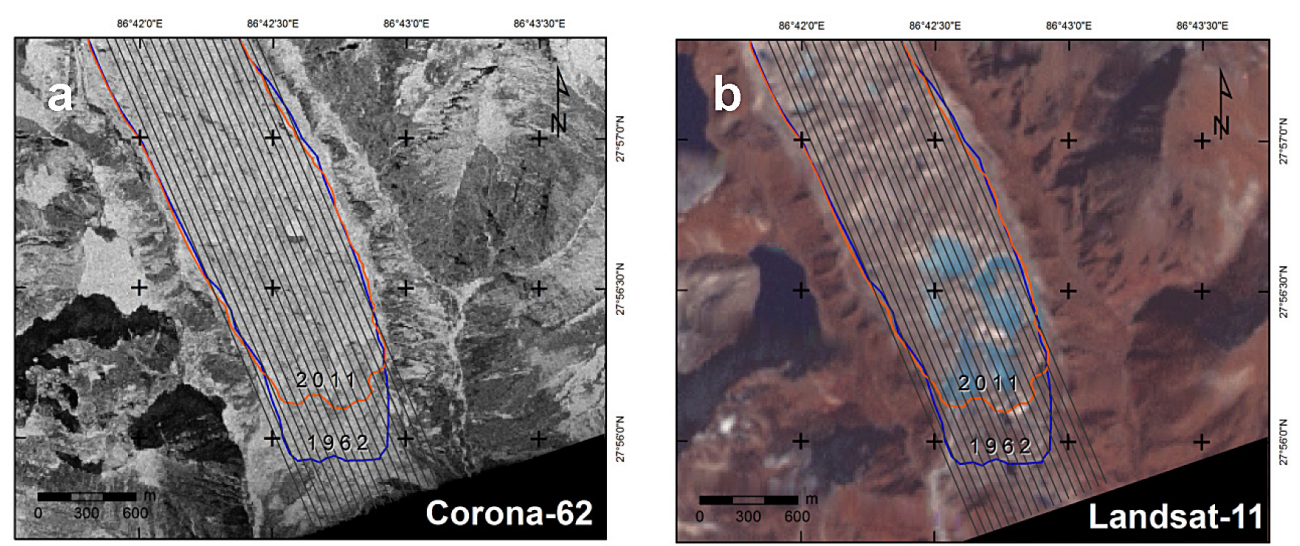

Figure 2. Glacier delineation in (a) panchromatic Corona-62; (b) SLC-off gap filled Landsat-11. The stripes in the images are meant for mean length change calculation.

panchromatic band $(15 \mathrm{~m})$ acquired by same satellite and on the same date.

\subsection{Data registration}

All of the imagery and maps were co-registered in the same coordinate system of WGS 1984 UTM Zone 45. The Landsat scenes were provided in standard terrain-corrected level (Level 1T) with the use of ground control points (GCPs) and necessary elevation data (https://earthexplorer.usgs.gov). The ALOS-08 image used here was orthorectified and corrected for atmospheric effects in Salerno et al. (2012). The Corona images were co-registered and rectified through the polynomial transformation and spline adjustment using more than 120 known GCPs obtained from the reference ALOS-08 image, including mountain peaks, river crossings, and identifiable rocks (Grosse et al., 2005; Lorenz, 2004). The polynomial transformation uses a least squares fitting algorithm and ensures the global accuracy of images (Rosenholm and Akerman, 1998), but does not guarantee local accuracy, whereas the spline adjustment improves for local accuracy, which is based on a piecewise polynomial that maintains continuity and smoothness between adjacent polynomials (Kresse and Danko, 2011). The overall root mean square error (RMSE) of GCPs in Corona registration was around $8 \mathrm{~m}$. The ERDAS IMAGINE $^{\circledR}$ software was used for processing the Corona image. The images were resampled to new pixel size $(8 \mathrm{~m})$ using the nearest neighbor method, most commonly applied resampling technique (Thompson et al., 2011; Brahmbhatt et al., 2012).

\subsection{Interpretation and mapping of glacier features}

The automated glacier mapping from satellite imagery is relatively accurate for clean ice, but it is hindered for the extensive debris-covered glaciers (Racoviteanu et al., 2008; 
Paul et al., 2013). Though few automated approaches to map the debris-covered parts exist, the results are less accurate and need intensive manual post-correction (Paul et al., 2004; Bhambri et al., 2011; Rastner et al., 2013). In this study, the glacier outlines were manually delineated using an on-screen digitizing method based on visual interpretation and falsecolor composite (FCC) developed from multispectral bands and assisted by the GDEM (Fig. 2a and b). The well established the band ratio (TM4/TM5) technique (Paul et al., 2004) was used to obtain a clear vision of snow and ice portion that assisted in the manual digitization. In the ablation part of the glacier where debris mantles are present, the delineation of the outline was performed by identifying lateral and frontal moraine and using the thermal band for the Landsat TM and ETM images. Streams issuing from beneath glacier were used as additional indication of its boundary.

For the $\Delta$ Term calculation, a band of stripes with a distance of $50 \mathrm{~m}$ between each stripe in the band was drawn parallel to the main flow direction of the glacier (Fig. 2), and the $\Delta$ Term was calculated as the average length of the intersection of the stripes with the glacier outlines (cf. Koblet et al., 2010; Bhambri et al., 2012).

The snow lines were retrieved manually from each satellite image and map. The snow lines on glaciers were distinguished from the images as the boundary between the bright white snow and the darker ice by visual interpretation and using FCC (Karpilo, 2009). The kinematic "Hess method" (Hess, 1904) was used to identify the snow line in the KHmap-50s, which involves the delineation of the boundary between the accumulation and ablation zone in a glacier using the inflection of elevation contour lines on the topographic map (Leonard and Fountain, 2003). Then, the SLA, as a measure of equilibrium-line altitude (ELA; McFadden et al., 2011; Rabatel et al., 2012), was calculated as the average altitude of the identified snow line using the ASTER GDEM. The SLA derived from the "Hess method" for the map represents the long-term ELA and, thus, does not indicate the position of the snow line in a particular year. However, the snow line position obtained from satellite imagery represents the transient snow line of the year that varies along the year, but remains stable after the end of summer, corresponding to the end of the ablation season (Rabatel et al., 2005; Pelto, 2011). The map-based SLA was useful for understanding the representativeness of the snow line position derived from the Corona image, which has some limitations for accurately identifying the snow line because of its panchromatic nature.

The ASTER GDEM along with glacier outlines were used to derive morphological features (slope, aspect, elevation). The mean elevation, aspect, and slope of each glacier were computed as arithmetic mean of each pixel of the GDEM intersected by the glacier outline. Concerning the glacier identification and cataloging, we followed the classification of Salerno et al. (2008), which in turn is based on the inventory of the International Centre for Integrated Mountain Develop- ment (ICIMOD) (Mool et al., 2001). In agreement with this study, we named only those glaciers whose area exceeded a threshold of $1 \mathrm{~km}^{2}$. In this way, we identified 29 glaciers, while the smaller glaciers $\left(<1 \mathrm{~km}^{2}\right)$ were categorized into "other glaciers" group.

\subsection{Uncertainty of measurement}

The measurement accuracy of the position of a single point in the space using GIS (geographical information system) is limited by resolution of source data used (i.e., the scale factor for cartography and the pixel resolution for satellite image), defined as LRE (linear resolution error), and by the error of referencing (RE, registration error). This approach is usually adopted in studies of glacial front ( $\Delta$ Term) (Hall et al., 2003; Ye et al., 2006). Concerning the glacier surface and debris coverage, the uncertainty of measurement was calculated as a product of the LRE and the perimeter (l) (Salerno et al., 2012). Then, the uncertainty with $\Delta$ Surf and $\Delta$ DebrisCov was derived according to standard error propagation rule, root of sum of squares (RSS) of the mapping error for the single scene. The co-registration errors were approximated and adjusted during the measurement. For further details on methodology adopted here for uncertainty analysis, we refer to Tartari et al. (2008) and Salerno et al. (2012). The elevation error associated with $\triangle$ SLA was estimated as the RSS between of the pixel resolution combined with the mean surface slope (Pelto, 2011) and the vertical error associated to the GDEM $(20 \mathrm{~m})$. Concerning the uncertainty in the SLA estimation due to temporal variation of surface elevation, we consider them negligible as there was no significant elevation change around SLA (Bolch et al., 2011) compared to the GDEM vertical accuracy, and thus have no impact on the results (Rabatel et al., 2013).

In this study, the uncertainty of measurement ranges from 6 to $30 \mathrm{~m}$ for $\Delta$ Term and from 21 to $35 \mathrm{~m}$ for $\Delta$ SLA. In both cases, as discussed below and shown in Fig. 3 and Table 2, the magnitude of the uncertainty is relatively low if compared with the observed changes, indicating good accuracy of the results. However, the errors associated with $\Delta$ Surf and $\Delta$ DebrisCov range from approximately 2 to $10 \%$ for both of variables. In particular, Fig. 3 and Table 2 indicate that until early 1990s, this uncertainty, due to low sensor resolution, is high and needs to be carefully considered in the change evaluations.

\subsection{The ELA-climate model}

To evaluate the role of climatic drivers in the $\triangle$ SLA, we used the simple ELA-climate model by Kuhn (1981). This model has been widely used in the European Alps (Kerschner, 1997), New Zealand (Hoelzle et al., 2007) and the Himalaya (Kayastha and Harrison, 2008) to estimate the climate drivers changes required for explaining the observed SLA change. The model (Eq.1) requires temperature lapse 

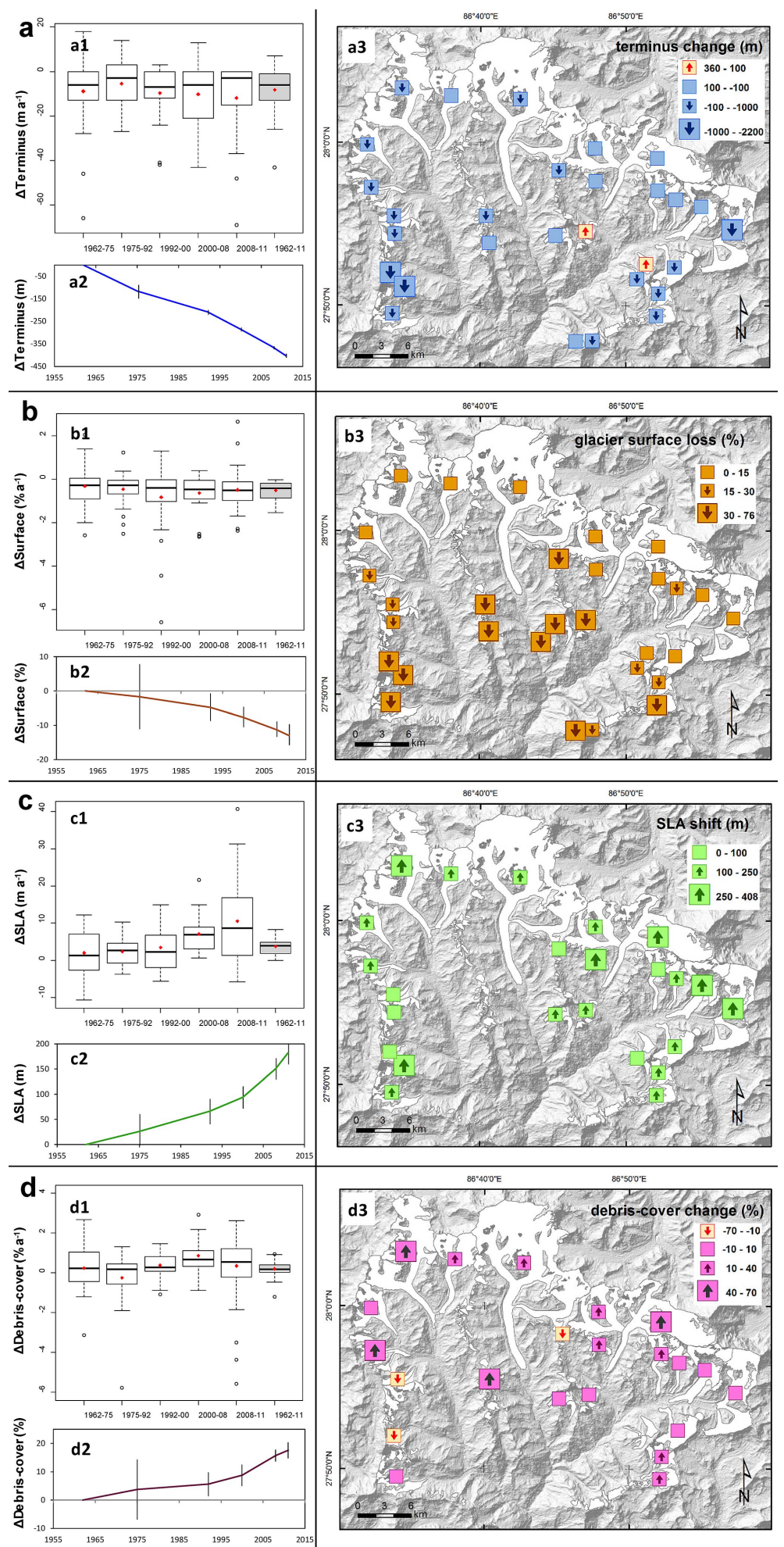

Figure 3. Spatio-temporal changes in Mt. Everest region; (a) terminus position change ( $\Delta$ Term), (b) surface area change ( $\Delta$ Surf), (c) shift of snow-line altitude $(\triangle \mathrm{SLA})$, and (d) debris area coverage change ( $\Delta$ DebrisCov). For each plot, upper left box plot represents the annual rates of change of the glaciers in the analyzed periods. The red point in the box indicates the mean. The lower left plot describes the cumulative changes with associated uncertainty. On the right side, the map represents the spatial variation of the glaciers. Data are in Table S1 of the Supplement. All percentages refer to the initial year of the analysis (1962). 
Table 2. Glacier changes from 1962 to 2011 in the Mt. Everest region.

\begin{tabular}{|c|c|c|c|c|c|c|c|c|c|c|c|}
\hline \multirow[t]{3}{*}{ Period } & \multicolumn{2}{|c|}{ Terminus position change ( $\Delta$ Term) } & \multicolumn{3}{|c|}{ Surface area change ( $\Delta$ Surf) } & \multicolumn{3}{|c|}{ Snow-line altitude shift ( $\triangle$ SLA) } & \multicolumn{3}{|c|}{ Debris coverage change ( $\Delta$ DebrisCov) } \\
\hline & $\begin{array}{l}\text { Cumulative } \\
\text { length }\end{array}$ & $\begin{array}{l}\text { Median annual } \\
\text { rate }\end{array}$ & $\begin{array}{l}\text { Cumulative } \\
\text { area }\end{array}$ & $\begin{array}{l}\text { Absolute } \\
\text { rate }\end{array}$ & $\begin{array}{l}\text { Median annual } \\
\text { rate }\end{array}$ & $\begin{array}{l}\text { Cumulative } \\
\text { altitude }\end{array}$ & $\begin{array}{l}\text { Mean annual } \\
\text { rate }\end{array}$ & $\begin{array}{l}\text { Median annual } \\
\text { rate }\end{array}$ & $\begin{array}{l}\text { Cumulative } \\
\text { area }\end{array}$ & $\begin{array}{l}\text { Absolute } \\
\text { rate }\end{array}$ & $\begin{array}{l}\text { Median annual } \\
\text { rate }\end{array}$ \\
\hline & (m) & $\left(\mathrm{ma}^{-1}\right)$ & $(\%)$ & $\left(\mathrm{km}^{2} \mathrm{a}^{-1}\right)$ & $\left(\% \mathrm{a}^{-1}\right)$ & (m) & $\left(\mathrm{ma}^{-1}\right)$ & $\left(\mathrm{ma}^{-1}\right)$ & $(\%)$ & $\left(\mathrm{km}^{2} \mathrm{a}^{-1}\right)$ & $\left(\% \mathrm{a}^{-1}\right)$ \\
\hline 1962-1975 & $-116 \pm 30$ & $-6.0 \pm 2.3$ & $-1.7 \pm 9.7$ & $-0.51 \pm 0.05$ & $-0.27 \pm 0.75$ & $26 \pm 35$ & $2.0 \pm 2.7$ & $1.3 \pm 2.7$ & $3.8 \pm 10.6$ & $0.25 \pm 0.01$ & $0.22 \pm 0.28$ \\
\hline 1975-1992 & $-208 \pm 11$ & $-2.6 \pm 1.9$ & $-4.8 \pm 4.1$ & $-0.75 \pm 0.08$ & $-0.29 \pm 0.65$ & $66 \pm 25$ & $2.4 \pm 2.2$ & $2.6 \pm 2.2$ & $5.7 \pm 4.4$ & $0.10 \pm 0.01$ & $0.19 \pm 0.68$ \\
\hline 1992-2000 & $-285 \pm 9$ & $-7.0 \pm 1.6$ & $-7.7 \pm 3.0$ & $-1.48 \pm 0.07$ & $-0.39 \pm 0.60$ & $94 \pm 22$ & $3.5 \pm 3.2$ & $2.3 \pm 3.2$ & $8.8 \pm 4.0$ & $0.35 \pm 0.02$ & $0.28 \pm 0.72$ \\
\hline 2000-2008 & $-367 \pm 6$ & $-5.8 \pm 1.1$ & $-11.3 \pm 2.3$ & $-1.83 \pm 0.06$ & $-0.46 \pm 0.38$ & $151 \pm 21$ & $7.1 \pm 2.7$ & $6.7 \pm 2.7$ & $15.8 \pm 2.6$ & $0.76 \pm 0.03$ & $0.68 \pm 0.56$ \\
\hline 2008-2011 & $-403 \pm 9$ & $-3.0 \pm 3.0$ & $-13.0 \pm 3.1$ & $-2.30 \pm 0.07$ & $-0.52 \pm 0.99$ & $182 \pm 22$ & $10.6 \pm 7.3$ & $8.7 \pm 7.3$ & $17.6 \pm 3.1$ & $0.55 \pm 0.02$ & $0.55 \pm 1.19$ \\
\hline 1962-2011 & $-403 \pm 9$ & $-6.1 \pm 0.2$ & $-13.0 \pm 3.1$ & $-1.08 \pm 0.03$ & $-0.42 \pm 0.06$ & $182 \pm 22$ & $3.7 \pm 0.5$ & $3.9 \pm 0.5$ & $17.6 \pm 3.1$ & $0.32 \pm 0.01$ & $0.20 \pm 0.06$ \\
\hline
\end{tabular}

rate, mass balance and radiation gradients, latent heat of fusion and length of melting season.

The model is expressed as,

$$
\frac{\partial b_{\mathrm{w}}}{\partial z} \Delta h+\delta b_{\mathrm{w}}=\frac{T}{L}\left[\frac{\partial R}{\partial z} \Delta h+\delta R+\gamma\left(\frac{\partial T_{\mathrm{a}}}{\partial z} \Delta h+\delta T_{\mathrm{a}}\right)\right],
$$

where $\Delta h=$ an observed change in ELA $(\mathrm{m}), T=$ length of melting season (d), $L=$ latent heat of fusion $\left(\mathrm{kJ} \mathrm{kg}^{-1}\right)$, $\gamma=$ constant $\left(\mathrm{MJ} \mathrm{m}^{-2} \mathrm{~d}^{-1} \mathrm{~K}^{-1}\right), \partial b_{\mathrm{w}} / \partial z=$ mass balance gradient $\left(\mathrm{kg} \mathrm{m}^{-2} \mathrm{~m}^{-1}\right), \partial T_{\mathrm{a}} / \partial z=$ temperature lapse rate $\left(\mathrm{K} \mathrm{m}^{-1}\right), \partial R / \partial z=$ net radiation gradient $\left(\mathrm{MJ} \mathrm{m}^{-2} \mathrm{~m}^{-1} \mathrm{~d}^{-1}\right)$, $\delta T_{\mathrm{a}}=$ bias in air temperature $(\mathrm{K}), \delta b_{\mathrm{w}}=$ bias in mass balance $\left(\mathrm{kg} \mathrm{m}^{-2}\right)$, and $\delta R=$ bias in net radiation $\left(\mathrm{MJ} \mathrm{m}^{-2} \mathrm{~d}^{-1}\right)$. We applied the model using the temperature lapse rate and the net radiation gradient calculated for this case study as described above, the mass balance gradient of $5 \pm 1 \mathrm{~mm}$ w.e. $\mathrm{a}^{-1} \mathrm{~m}^{-1}$ provided by Fujita et al. (2006), $T=100 \mathrm{~d}$; $L=334 \mathrm{~kJ} \mathrm{~kg}^{-1}$, $\gamma=1.7 \mathrm{MJ} \mathrm{m}^{-2} \mathrm{~d}^{-1} \mathrm{~K}^{-1}$ as described in Kuhn (1981).

Concerning the limitations of this model, we need first of all to consider that the SLA as a proxy to ELA; we assume that there is little, or no ablation during winter season. Furthermore, this model just considers a single mass balance gradient value, while some authors, e.g., Wagnon et al. (2013) recently found an average mass balance gradient of $4.5 \mathrm{~mm}$ w.e. $\mathrm{a}^{-1} \mathrm{~m}^{-1}$ for Mera Glacier (in the Dudh Koshi Basin), similar to the gradient provided by Fujita et al. (2006), but point out its variability in relation to local topographic conditions.

\subsection{Statistical analysis}

The normality of the data is tested using the Shapiro-Wilk test. The null hypothesis for the Shapiro-Wilk test is that samples $\mathrm{x} 1, \mathrm{x} 2 \ldots \mathrm{xn}$ belong to a normally distributed population. If the $p$ value $(p)>0.05$, we consider the series to be normally distributed; otherwise, it is not normal (Shapiro and Wilk, 1965). We used the paired t test for comparing the means of two series. The null hypothesis is that the difference between paired observations is zero $(p<0.05)$ (Walford, 2011). If the series were not normal, we first used a $\log$ transformation to apply the paired t test for a normally distributed series. The parallelism between the regressions of SLAs time series is tested by the analysis of covariance
(ANCOVA) (Dette and Neumeyer, 2001). All tests are implemented in the R software environment.

\section{Results}

Table 2 provides a general summary of the changes that occurred from 1962 to 2011. Our main findings, however, are visualized in Fig. 3, which has been subdivided into four sections $(a-d)$, corresponding to four selected indicators of change (terminus, surface area, SLA, and debris coverage). The spatial differences are presented on the right side of each section, and the temporal changes are shown on the left side. On the left side, in the upper panel of each section, the box plots show the annual rates of change for the analyzed period, while the cumulative changes and their associated uncertainties are presented in the lower panels. All data presented and discussed in this paper are reported in Tables S1 and S2 of the Supplement.

\subsection{Glacier terminus position change}

Overall, the Mt. Everest glaciers experienced a $\Delta$ Term of $-403 \pm 9 \mathrm{~m}(\sigma=533 \mathrm{~m})$ (Fig. $3 \mathrm{a} 2$ and Table 2$)$ as the mean ( $-301 \pm 9 \mathrm{~m}$ as median), corresponding to an annual mean rate of $-8.2 \pm 0.2 \mathrm{ma}^{-1}\left(\sigma=10.8 \mathrm{ma}^{-1}\right)$ and a median value equal to $-6.1 \pm 0.2 \mathrm{~m} \mathrm{a}^{-1}$ from 1962 to 2011 (Fig. 3a1 and Table 2). We found that the distribution of the annual retreat rates in all observed periods (Shapiro-Wilk test) was always far from normal because a few glaciers experienced a retreat that was much higher than the retreat of others (see box plots in Fig. 3a1). Therefore, we consider the median values of $\Delta$ Term to be more representative of the change.

Figure $3 \mathrm{a} 2$ depicts a generally continuous and constant retreat over the last 50 years. We thus tested these properties of the observed trend. First, we evaluated the continuity of the process, checking whether each period showed a retreat that was significantly different from zero. Second, we tested the possible acceleration of the retreat by comparing the annual rates of change between each period and previous. In both cases, we first provided a log transformation of the data to apply the paired $t$ test for a normally distributed series. In the first case, we observed that the retreat of each period was always significantly different from zero 
(the weakest significance was found in the 1962-1975 period). However, when evaluating the possible acceleration, we found no significant differences among the annual rates of change ( $p>0.1)$. The result of this test can be further observed in Fig. 3a1, considering the distribution of the median annual rates. In fact, the retreat rate has decreased since 1992, although not significantly.

In Fig. 3a3, we can observe the spatial distribution for the overall period of analysis of 1962-2011. We observed that two glaciers (Duwo and Cholo) experienced an overall advance. These glaciers advanced until 1992, and then they began retreating, similarly to the other glaciers. Furthermore, we can observe that most of the western glaciers have retreated more than the eastern ones, except for the Imja Glacier.

As mentioned above, for the first years of the analysis, we used the Corona-62 with two topographic maps (KHmap-50s and TISmap-63). Comparing these data sources with the Landsat-75, we observed that the KHmap$50 \mathrm{~s}\left(6.1 \pm 1.9 \mathrm{~m} \mathrm{a}^{-1}\right)$ shows a closer mean retreat to the Corona-62 $\left(8.2 \pm 0.2 \mathrm{~m} \mathrm{a}^{-1}\right)$ than to the TISmap-63 $\left(13.3 \pm 2.6 \mathrm{~m} \mathrm{a}^{-1}\right)$, which seems to overestimate the $\Delta$ Term, probably due to inaccurate representation of the glacier boundary in TISmap-63 as found for other topographic maps in the Himalaya (Bhambri and Bolch, 2009).

\subsection{Glacier surface area change}

The Mt. Everest glaciers experienced a $\Delta$ Surf of $-52.8 \pm 11.0 \mathrm{~km}^{2}$ (from 404.6 to $351.8 \mathrm{~km}^{2}$ ), corresponding to an overall change of $-13.0 \pm 3.1 \%\left(-0.27 \pm 0.06 \% \mathrm{a}^{-1}\right)$, from 1962 to 2011 (Fig. 3b2 and Table 2). The mean annual shrinkage rate calculated for each glacier in the period from 1962-2011 was $0.51 \pm 0.06 \% \mathrm{a}^{-1}(\sigma=0.38)$, and the median rate was $0.42 \pm 0.06 \% \mathrm{a}^{-1}$ (Fig. 3b1). By testing the annual loss rate (Shapiro-Wilk test) of each glacier in each observed period, we observed (similarly to the terminus retreat) that it was never normally distributed (see box plots in Fig. 3b1). Therefore, in this case as well, we consider it to be more representative of change in the median values.

We can observe a continuous surface area loss since the 1960s that appears to have accelerated in recent years (Fig. 3b2). In fact, the rate of median annual area loss was $0.27 \pm 0.75 \% \mathrm{a}^{-1}$ in $1962-1975$ and has increased to the rate of loss of $0.48 \pm 0.55 \% \mathrm{a}^{-1}$, in 2000-2011 period (Fig. 3b1). We thus tested these trend properties using same procedure that we had adopted for evaluating the $\Delta$ Term. In this case, we again first provided a log transformation of the series. We observed that the surface area loss of each period was always significantly different from zero. The weakest significance was found in the 1962-1975 period. In fact, Fig. 3b2 and Table 2 show lower observed surface change (1.7\%) for this period, which, although significant, is associated with the highest uncertainty $(9.7 \%)$. However, in evaluating the possible acceleration of the surface area losses, we found slight but statistically insignificant acceleration of the surface area between the rates of area loss in the 1962-1992 period (median $\left.0.35 \pm 0.13 \% \mathrm{a}^{-1}, 0.015 \mathrm{~km}^{2} \mathrm{a}^{-1}\right)$ and the $1992-2011$ period (median $0.43 \pm 0.25 \% \mathrm{a}^{-1}, 0.039 \mathrm{~km}^{2} \mathrm{a}^{-1}$ ) indicating that for the 1992-2011 period, each glacier is retreating on average at nearly the double rate than the previous period.

The area loss observed in the first period (1962-1975) using Corona-62 and Landsat-75 was robust using different data sources, as described in the methods section and shown in Table 1. Comparing the KHmap-50s with the Landsat75 , we obtain a glacier area loss of $0.22 \pm 0.64 \% \mathrm{a}^{-1}$, which is very close to the value obtained using Corona- 62 $\left(0.27 \% \mathrm{a}^{-1}\right)$. Moreover, for some glaciers, we were able to substitute high resolution Corona-70 with Landsat-75 to provide information about the accuracy of the Landsat data. The comparison of Corona- 62 and Corona-70 provided a mean rate of $0.26 \% \mathrm{a}^{-1}$, confirming that between late $1950 \mathrm{~s}$ and early 1970 s, the glacier surface losses were very small.

Figure $3 \mathrm{~b} 3$ represents a distinct spatial pattern of glacier $\Delta$ Surf. All of the glaciers experienced surface area losses between 1962 and 2011. However, the southern glaciers lost higher surface area than the northern glaciers.

\subsection{Snow Line Altitude change}

Overall, from 1962 to 2011, the SLA of Mt. Everest glaciers shifted upward by $182 \pm 22 \mathrm{~m}(\sigma=114)$ from $5289 \mathrm{~m}$ to $5471 \mathrm{~m}$ a.s.l.; this increase corresponds to a mean annual rate of $3.7 \pm 0.5 \mathrm{~m} \mathrm{a}^{-1}(\sigma=2.3)$ (Fig. 3c1, 3c2, and Table 2). The distribution of the annual rate of the SLA shift in all of the observed periods is in this case normal (Shapiro-Wilk test; see box plots in Fig. 3c1). Therefore, the mean values are suitable for describing the $\triangle$ SLA.

In Fig. 3c2, the overall trend in $\triangle$ SLA shows a continuous upward shift in the last 50 years. In fact, in Fig. 3c1, we can observe that the mean annual upward rate of the SLA was $2.0 \pm 2.7 \mathrm{~m} \mathrm{a}^{-1}$ in $1962-1975$ and achieved the highest shift rate of $10.6 \pm 7.3 \mathrm{~m} \mathrm{a}^{-1}$ in the 2008-2011 period. In this case, we tested the possible continuity and acceleration of trend following the same procedure applied above. We observed a statistically significant upward shift of the SLA $(p=0.02)$, except during the first period of 1962-1975. Moreover, we found significant differences $(p<0.001)$ in the annual upward shift of the SLA between periods 1962-1992 $\left(\right.$ mean $\left.=2.2 \pm 0.8 \mathrm{~m} \mathrm{a}^{-1}\right)$ and 1992-2011 $\left(\right.$ mean $\left.=6.1 \pm 1.4 \mathrm{~m} \mathrm{a}^{-1}\right)$.

Figure $3 \mathrm{c} 3$ represents the spatial distribution of the SLA for the overall 1962-2011 period. In this case, the spatial pattern is not distinct. The glaciers with the minimum and maximum SLA in 2011 are Cholo (5152 m) and Imja (5742 $\mathrm{m})$, respectively.

Furthermore, as mentioned above, we calculated the SLA using the KHmap-50s with the "Hess method," which provides an average position of the average snow line for the 1950s. We observed the SLA at $5272 \mathrm{~m}$ a.s.1., which is not 
very different from the SLA at $5289 \mathrm{~m}$ a.s.l., as derived from Corona-62.

\subsection{Glacier debris-covered area change}

Overall, the debris-covered area has increased by $17.6 \pm 3.1 \% \quad\left(0.36 \pm 0.06 \% \mathrm{a}^{-1}\right) \quad$ (Fig. $3 \mathrm{~d} 2$ and Table 2) from 1962 to 2011. The mean annual increase rate calculated for each glacier in the 1962-2011 period is $0.28 \pm 0.06 \% \mathrm{a}^{-1}(\sigma=0.34)$, and the median rate is $0.20 \pm 0.06 \% \mathrm{a}^{-1}$ (Fig. 3d1). The debris-covered area was approximately $24.5 \%$ of the total glacier area in 1962 and $32.0 \%$ in 2011. In the same area, Nuimura et al (2012) reported $34.8 \%$ of debris-covered area in 2003-2004. In correspondence of the increase of debris coverage we observed the consequent decreasing of debris free area (Fig. S2 in the Supplement). Testing the annual rate of $\Delta$ DebrisCov with the Shapiro-Wilk test, we observed that the increase of the debris-covered area is not normally distributed among all glaciers (Fig. 3d1). Therefore, we also consider the median values to be more representative of change in the case of $\triangle$ DebrisCov.

In Fig. 3d2, we present the overall $\Delta$ DebrisCov trend, which indicates a general continuous increase of debris cover area over the last 50 years. The debris cover increase began to be statistically significant for each glacier only after $2000(p<0.01)$ years. Evaluating the possible acceleration, we found no significant differences among the annual rates of changes $(p>0.1)$. The result of this test can be observed in Fig. 3d1, which considers the distribution of median annual rates. Since 2000, the rates of debris-covered area change appear to be decreasing, although not significantly. Furthermore, we observed a significant relationship between $\Delta$ DebrisCov and $\triangle$ SLA during the 1962-2011 period $(r=0.79, p<0.01)$. In this regards, Bolch et al. (2008) observed that debris cover increases during periods of high ablation as more englacially stored debris is exposed. In Fig. 3d3, we can observe the spatial distribution of the debriscovered area (\%) in the overall period of analysis of 19622011. We observe that the glaciers experienced an overall increase in the debris-covered area, except the glaciers Imja, Kdu_gr125, Langdak, and Langmuche for which local effects could have played important role.

\section{Discussion}

\subsection{Comparison among terminus position change, surface area loss and the relevant mass budget observations}

Mass budget measurements are the main index used for climate change impact studies on glaciers, as by Fujita et al. (2006), Bolch et al. (2011), Nuimura et al. (2012), and Gardelle et al. (2013) as this index can be directly linked to climate while length and area change show a delayed signal

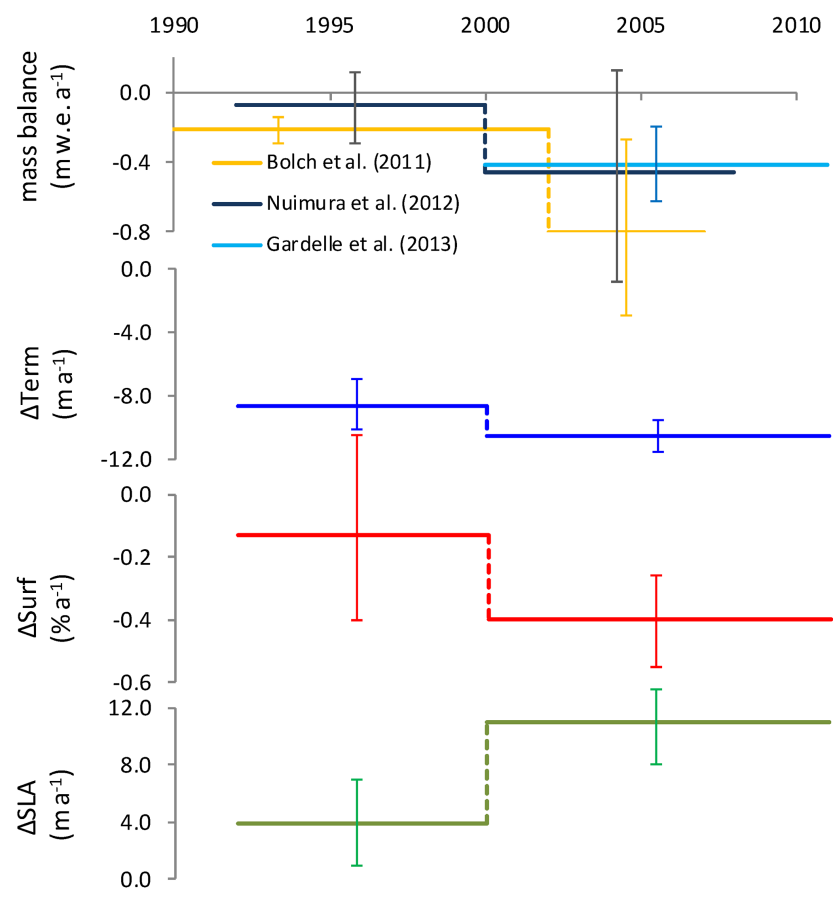

Figure 4. Comparison for 10 selected glaciers using the terminus position change $(\Delta$ Term $)$, glacier surface area loss $(\Delta$ Surf $)$, and shift of snow-line altitude ( $\triangle$ SLA) calculated in this study and relevant mass downwasting observations of Bolch et al. (2011), Nuimura et al. (2012). Furthermore, the mass balance data of Gardelle et al. (2013) are reported.

(Oerlemans, 2001). However, conducting mass-balance measurements is not a trivial task, due to the technical requirements and practical constraints (Bolch et al., 2012); these measurements are thus not often used in extensive studies. Most of the authors, in fact, analyze glacier terminus position and surface (Bolch et al., 2012; Yao et al., 2012; Kulkarni et al., 2011; Scherler et al., 2011). However, we need to consider the limitations of these variables especially for debriscovered glaciers, which experience more downwasting than area loss (Bolch et al., 2008; Tennant et al., 2012). In this regard, we decided to compare our findings in terms of $\Delta$ Term, $\Delta$ Surf, and $\triangle$ SLA with the corresponding mass budget information provided by other authors to evaluate whether these factors are suitable indices in this context. We present here in Table 3 and Fig. 4 the mass balance data derived from geodetic methods for 10 glaciers located in our study area according to Bolch et al. (2011), Nuimura et al. (2012), and Gardelle et al. (2013). Bolch et al. (2011) and Nuimura et al. (2012) find a higher mass loss rate during the last decade. Furthermore, these estimations are reinforced by the rate provided in Gardelle et al. (2013) for the period (2000-2011).

Figure 4 shows that, for the same glaciers, we observed a $\Delta$ Term that was only slightly higher in the second period (2000-2011) than in the previous one (1992-2000), while the $\Delta$ Surf and the $\Delta$ SLA were both approximately 4 times 
Table 3. Rates of mass balance, $\Delta$ Term, $\Delta$ Surf, and $\Delta$ SLA for 10 common glaciers.

\begin{tabular}{llll}
\hline Variable & Period & Change rate & Source \\
\hline Mass balance & $1970-2002$ & $-0.21 \pm 0.10$ & Bolch et al. (2011) \\
$\left(\mathrm{m} \mathrm{w.e.}^{-1}\right)$ & $2002-2007$ & $-0.79 \pm 0.52$ & \\
\cline { 2 - 3 } & $1992-2000$ & $-0.07 \pm 0.20$ & Nuimura et al. (2012) \\
& $2000-2008$ & $-0.45 \pm 0.60$ & \\
\cline { 2 - 3 } & $2000-2011$ & $-0.41 \pm 0.21$ & Gardelle et al. (2013) \\
\hline$\Delta$ Term $\left(\mathrm{m} \mathrm{a}^{-1}\right)$ & $1992-2000$ & $-8.6 \pm 1.6$ & This study \\
& $2000-2011$ & $-10.6 \pm 1.0$ & \\
\hline \multirow{2}{*}{$\Delta$ Surf $\left(\% \mathrm{a}^{-1}\right)$} & $1992-2000$ & $-0.13 \pm 0.30$ & \\
& $2000-2011$ & $-0.40 \pm 0.15$ & \\
\hline$\Delta$ SLA $\left(\mathrm{m} \mathrm{a}^{-1}\right)$ & $1992-2000$ & $3.9 \pm 3.2$ & \\
& $2000-2011$ & $10.9 \pm 2.8$ & \\
\hline
\end{tabular}

higher in the last decade, as observed using mass budget data. Such behavior is expected given the lag in response time because downwasting leads to more volume loss then retreat (Oerlemans, 2001; Hambrey and Alean, 2004). This comparison shows that, for this region, the glacier surface area loss and the shift of snow-line altitude (i.e., the shift of late summer snow line) can be considered suitable indicators for a broad description of glacial response to the recent climate change.

\subsection{Comparison with other parts of the Himalaya and high-mountain Asia}

Bolch et al. (2012) recently noted that length and surface area changes suggest that most Himalayan glaciers have been retreating since the mid-19th century. Yao et al. (2012) reported the glacier status over the past 30 years in the Himalaya and the Tibetan Plateau. They observed that the shrinkage generally decreases from the Himalaya to the continental interior, and it is most pronounced in the southeastern Himalayan region.

In Nepal, Yao et al. (2012) considered only three benchmark glaciers for evaluating the Term retreat during the 1974-1999 period and the same set of glaciers analyzed here (Koshi Basin) for evaluating the surface area loss, but for a shorter period (1976-2000) than in the present study. They reported a $\Delta$ Term of $6.9 \mathrm{~m} \mathrm{a}^{-1}$ based on the three glaciers located outside our study area. During a similar period (19752000), we calculated a median retreat of $4.4 \pm 0.8 \mathrm{~m} \mathrm{a}^{-1}$ for all 29 glaciers and a median retreat of $6.1 \pm 0.2 \mathrm{~m} \mathrm{a}^{-1}$ for the 1962-2011 period. Further, in comparing the same set of glaciers and during the same period we found a termini retreat rate $\left(9 \mathrm{~m} \mathrm{a}^{-1}\right)$ lower than the rate $\left(19 \mathrm{~m} \mathrm{a}^{-1}\right)$ provided by Bajracharya and Mool (2009), probably due to the higher resolution of data source used in this study (furthermore in Fig. S1 of the Supplement). Concerning the Surf area loss,
Yao et al. (2012) reported a decrease of $0.15 \% \mathrm{a}^{-1}$, while during a similar period (1975-2000), we calculate an area loss of $0.25 \pm 0.40 \% \mathrm{a}^{-1}$. We can observe that although the retreat rates are comparable between the studies, with regards to $\Delta$ Surf, we observed a greater area loss; this difference could be because both satellites used in 1975 and 1976 (Landsat MSS) had a broad resolution $(60 \mathrm{~m})$ leading to a large uncertainty in the estimates and, hence the studies take the uncertainty into account. Moreover, we sustain that the recent area loss estimation $\left(0.63 \% \mathrm{a}^{-1}\right)$ provided by Shangguan et al. (2014) for the same set of glaciers analyzed here during the 1976-2009 period is overestimated probably for the misleading glacier boundary interpretation especially in the upper glacier area in 1976 due to the low resolution Landsat MSS image and adverse snow conditions, while our interpretation is reinforced by the higher resolution of Corona-70 image. Moreover, we point out that the present study corresponds to zone III of the analysis in Yao et al. (2012), defined by the authors as the central Himalaya and including both the north (Tibet) and south (Nepal) slopes of the Himalayan range, represented by the Mt. Qomolangma $\mathrm{Na}-$ tional Nature Preserve and the Koshi Basin, respectively. The average termini retreat and area loss rates for zone III have been established by the authors at $6.3 \mathrm{~m} \mathrm{a}^{-1}$ and $0.41 \% \mathrm{a}^{-1}$, respectively. However, the glacier behavior is not homogenous in the central Himalaya, so this mean loses significance, particularly considering the different area loss observed for the northern and southern parts. In fact, according to Nie et al. (2010) and as reported by Yao et al. (2012), the area loss rate is $0.50 \% \mathrm{a}^{-1}(1976-2006)$ in the north; during the same period in the south, the area loss rate is about half that, according to the present study, and one third of that, according to Yao et al. (2012). Likewise, an area loss of $0.3 \% \mathrm{a}^{-1}$ for the 1974-2008 period was provided by Ye et al. (2009) on the northern side, and $0.15 \% \mathrm{a}^{-1}$ for the period ranging from the 1950 s to 1992 (similar to our observation $0.16 \% \mathrm{a}^{-1}$ 

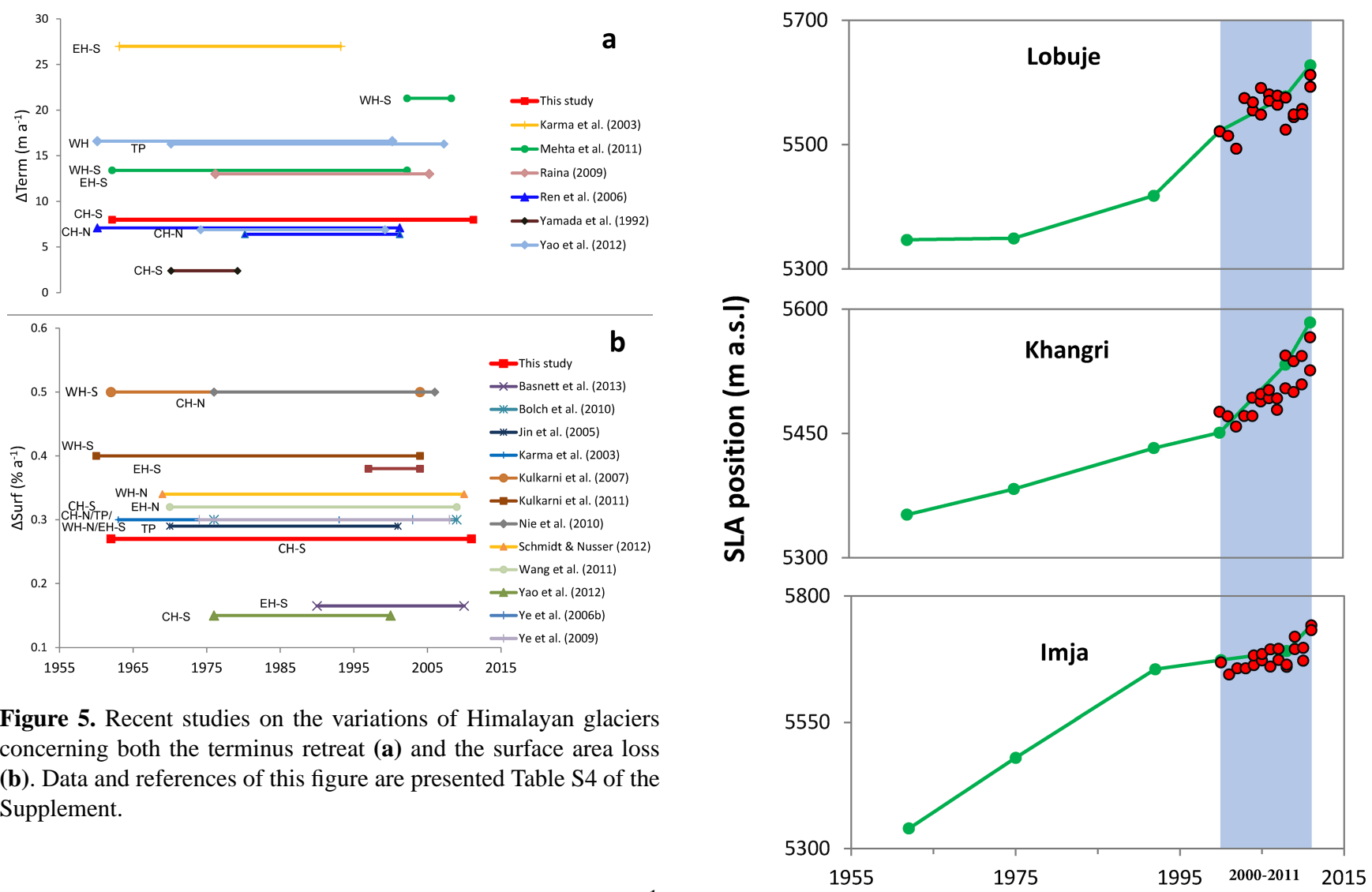

during 1962-1992) (Salerno et al., 2008) and $0.12 \% \mathrm{a}^{-1}$ for selected glaciers for the 1962-2005 period (Bolch et al., 2008a), both located in the southern side. Therefore, to explore possible differences in the surroundings of the south slopes of Mt. Everest, we decided to separately consider the northern and southern parts of the central, western and eastern Himalaya $(\mathrm{CH}, \mathrm{WH}$, and $\mathrm{EH}$, respectively, with the suffixes $-\mathrm{N}$ and $-\mathrm{S}$ ). Following this scheme, the present case study and all of Nepal are located in CH-S. Evidence from the Tibetan Plateau (TP) is presented separately (Fig. 1a).

Figure 5 reports the most recent studies on the changes of Himalayan glaciers concerning both the terminus retreat (Fig. 5a) and the area loss (Fig. 5b). In general, we can observe that the CH-S, in terms of both $\Delta$ Term and $\Delta$ Surf,registered among the lowest changes of the entire Himalaya and the TP. The northern and the southern central Himalaya (CH-N and $\mathrm{CH}-\mathrm{S}$ ) share the lower termini retreat, while the record is held by the $\mathrm{CH}-\mathrm{S}$ glaciers regarding the lowest area loss, if we consider that the recent study of Basnett et al. (2013) on Sikkim Himalaya, although this area is geographically part of EH-S, is adjacent to the eastern $\mathrm{CH}$ $\mathrm{S}$ border. The lower $\Delta$ Term and $\Delta$ Surf observed in $\mathrm{CH}-\mathrm{S}$ region, compared with the other parts of the Himalaya and the TP, can be ascribed both to the abundance of debris cover (Scherler et al., 2011; Bolch et al., 2012) and to the altitude of these glaciers. Scherler et al. (2011) defined the southern central Himalaya as the region with the glaciers that contain the highest debris coverage $(\sim 36 \%)$ and considered the abun-

Figure 6. Validation of the SLA trend of 1962-2011 period (green line) for three selected glaciers (Lobuje, Khangri, and Imja) using the satellite imagery reported in Table 1 with additional 20 Landsat ETM+ imagery (red points) of 2000-2011 period (shaded region).

dance of debris coverage to be a significant factor in reducing the melt rate of these glaciers, preserving their surfaces from further recession. In this regards, we observed a strong direct relationship between $\Delta$ DebrisCov and $\Delta$ Term (divided by the length of the ablation area) $(r=0.87, p<0.01$ for 1962-2011 period) which means that the glaciers who have increased the debris coverage have experienced a reduced termini retreat. We remember here that, Bolch et al. (2008a, 2011) noted the highest rate of mass downwasting is located in the transition zone between the active and the stagnant glacier parts of the debris covered glaciers.

However, of no less importance is the altitude of these glaciers. In fact, as reported by Bolch et al. (2012), with a mean elevation of $5600 \mathrm{~m}$ a.s.l., the highest glaciers of the Himalayan range are located in $\mathrm{CH}$. In this regards, Wagnon et al. (2013), in the same zone analyzed here (Dudh Koshi Basin) show that a low elevation glacier (Phokalde, 5430 to $5690 \mathrm{~m}$ a.s.l.) presents a more negative mass balance $\left(0.72 \pm 0.28 \mathrm{~m}\right.$ w.e. $\left.\mathrm{a}^{-1}\right)$ than a higher elevation one (Mera, 4940 to $6420 \mathrm{~m}$ a.s.1.) which experienced a mass balance rate of $-0.23 \pm 0.28 \mathrm{~m}$ w.e. $\mathrm{a}^{-1}$ between 2009 and 2012. On the 

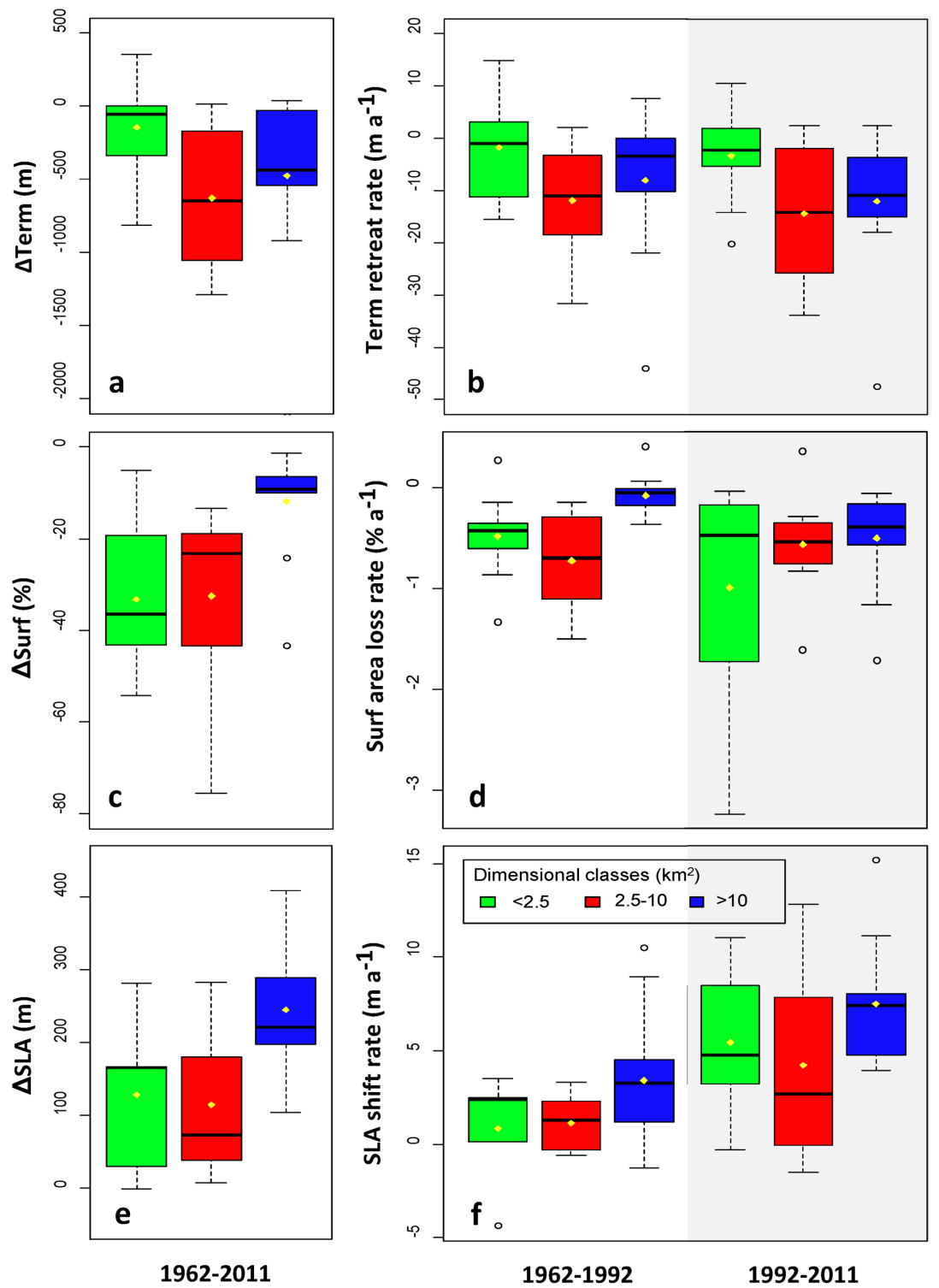

Figure 7. Differences among three-dimensional classes of glaciers $\left(<2.5 \mathrm{~km}^{2} ; 2.5-10 \mathrm{~km}^{2} ;>10 \mathrm{~km}^{2}\right)$ in terms of cumulative changes in the overall 1962-2011 period: (a) terminus retreat (m); (c) surface area loss (\%); (e) shift of SLA (m). Differences in terms of annual rate of change between 1962-1992 and 1992-2011 periods; (b) annual terminus retreat rate $\left(\mathrm{m} \mathrm{a}^{-1}\right)$; (d) annual surface area loss rate (\% $\left.\mathrm{a}^{-1}\right)$; (f) shift rate of SLA $\left(\mathrm{m} \mathrm{a}^{-1}\right)$. All percentages refer to the initial year of the analysis (1962).

south slope of Mt. Everest, the area-weighted mean elevation of the glaciers is $5720 \mathrm{~m}$ a.s.l in 2011. Therefore, it is highly likely that the summit of the world has preserved these glaciers from excessive melting better than in the other parts of the Himalaya and the TP.

\subsection{Snow-line altitude change and climate relation}

The snow-line is characterized by seasonal fluctuations (Mernild et al., 2013; Pelto et al., 2013). To avoid the possible risk of introducing this variability into the inter-annual analysis, we enforced our 1962-2011 trend exploiting the avail- ability of 20 Landsat ETM+ imagery for 2000-2011 period. Three glaciers were selected according to their size: Lobuje, Khangri and Imja (Table S3 in the Supplement). Figure 6 shows, for all three cases, that the trend estimated just using three time steps (year 2000, 2008, and 2011) (green line) represents correctly the upward shift of SLA described using all available imagery. We statistically ensure this statement testing the parallelism of SLAs time series. In all three cases, the test shows all three comparisons are significantly parallel $(F=1.0, p>0.3 ; F=1.7, p>0.2 ; F=0.0, p>0.9$ for Lobuje, Khangri, and Imja, respectively). 
Bolch et al. (2012), considering the mean elevation as a rough proxy for the ELA, reported an ELA of about $5600 \mathrm{~m}$ a.s.l. in $\mathrm{CH}$. For the south slope of the Mt. Everest region, Owen and Benn (2005) indicated an elevation of $5200 \mathrm{~m}$ a.s.l. for the 1980s, while Asahi (2010) noted an altitude of $5400 \mathrm{~m}$ a.s.1. in the early 1990s. In this study, comparing the same years, we observed a SLA position of $5315 \mathrm{~m}$ a.s.l. in 1975 and $5355 \mathrm{~m}$ a.s.l. in 1992, corresponding to a lower shift. Kayastha and Harrison (2008) observed an upward of ELA by $0.9 \pm 1.1 \mathrm{~m} \mathrm{a}^{-1}(29 \pm 35 \mathrm{~m})$ during the 1959-1992 period using the toe-to-headwall altitude ratio (THAR) method with TISmap-63 and the aerial photos of 1992, from which the OTNmap-92 was delineated. In a comparable period (1962-1992), we calculated an upward shift of SLA by $2.2 \pm 0.8 \mathrm{~m} \mathrm{a}^{-1}(66 \pm 24 \mathrm{~m})$ based on satellite data. The difference between the calculation of Kayastha and Harisson (2008) and our calculation is mainly due to different methodologies applied and the data set used. Surely, if a suitable scene is available, the SLA derived directly from the satellite imagery is more representative of a specific year than the map-based estimation.

The SLA trend qualitatively indicates the mass-balance variation of glaciers (Chinn et al., 2005). Variations in SLA derived from satellite imagery can be used as a proxy for providing indications of local climate variability (Fujita and Nuimura, 2011; McFadden et al., 2011, Rabatel et al., 2012). In this case study, the SLA is significantly moving upwards, with an accelerated rate after 1992, indicating that the glaciers in this region are experiencing an increasingly negative mass balance as it is suggested with the mass downwasting observations of Bolch et al. (2011) and Nuimura et al. (2012) (Fig. 4). The observed upward shift of the snow line could be interpreted as a direct response to hightemperature events, reduced precipitation, or increased solar radiation (Hooke, 2005). To evaluate the role of climatic drivers in the $\triangle$ SLA, we used the simple ELA-climate model by Kuhn (1981). Using this model, we estimated that for the observed $182 \mathrm{~m}$ upward shift of SLA in the 19622011 period, a temperature increase of $1.1^{\circ} \mathrm{C}$, or a precipitation decrease of $543 \mathrm{~mm}$, or a solar imbalance increase of $1.8 \mathrm{MJ} \mathrm{m}^{-2} \mathrm{~d}^{-1}$ is required. By reacting to this climate perturbation, the SLA shifted by $182 \mathrm{~m}$ upward.

Concerning the temperatures, on the south slope of Mt. Everest, Diodato et al. (2012) established the longest temperature series (1901-2009) for this high elevation area, taking advantage of both land data obtained from the "Pyramid" meteorological observatory $(5050 \mathrm{~m})$ for the 1994-2005 period and gridded temperature data for extending the time series. They observed an increasing trend of $0.01^{\circ} \mathrm{Ca}^{-1}$ in the last century $\left(+0.9^{\circ} \mathrm{C}\right)$, which can be attributed mainly to the 1980-2008 period $\left(0.03^{\circ} \mathrm{Ca}^{-1},+0.8^{\circ} \mathrm{C}\right)$. Likewise, Lami et al. (2010), using only the land data from the "Pyramid" stations $(5050 \mathrm{~m})$ for the 1992-2008 period, reported an increasing trend of $0.04^{\circ} \mathrm{Ca}^{-1}\left(+0.7^{\circ} \mathrm{C}\right)$. However, we need to consider that the recent global warming trend is more dom- inant in the winter season (Jones and Moberg, 2003). Cook et al. (2003) re-examined a longer Kathmandu mean temperature record and compared it with a gridded data set based on records from neighboring northern India; both showed a cooling trend in the monsoon season (June to September) for the 1901-1995 period. Summer cooling trends during the last few decades of the twentieth century have also been documented for the Tibetan Plateau (Liu and Chen, 2000). According to Diodato et al. (2012), the temperature in this zone increased by more than $+0.8 /+0.9^{\circ} \mathrm{C}$ during our study period (1962-2011), corresponding to $70-80 \%$ of the temperature increase required to justify the upward shift of SLA $\left(+1.1^{\circ} \mathrm{C}\right)$, even if, this rise has probably not occurred in the summer period when the ablation process is concentrated and thus, less impacting on glaciers shrinkage.

For the precipitation, Sharma et al. (2000) showed an increased tendency from 1948-1993 in the Dudh Koshi Basin. Additionally, Salerno et al. (2008) noted an increasing trend for higher elevations until the early 1990s. From these years of analysis, many researchers have highlighted a mainly decreasing trend in the Himalayan range (Wu, 2005; Thompson et al., 2006; Naidu et al., 2009). According to Yao et al. (2012), using the Global Precipitation Climatology Project (GPCP) data, the Asian monsoon lost $173 \mathrm{~mm}$ in this region for the 1979-2010 period, with a real decreasing trend starting from the early 1990s (mean value between grid 9 and 11 in Fig. S18 of their paper). We have already noted that we would have recorded a decrease of $543 \mathrm{~mm}$ if the only factor responsible for the higher SLA were the precipitation. Current knowledge shows that precipitation can be held responsible for approximately $30 \%$ of the negative balance of glaciers in the study region (e.g., Yao et al., 2012; Palazzi et al., 2013).

Establishing the influence of solar radiation on the negative mass balance of these glaciers is much more difficult considering the complete global lack of long-term measurements of this variable at high elevations. For the Northern Hemisphere, Wild et al. (2005) reported a general decrease of sunlight over land surfaces, using the popular expression "global dimming," on the order of 2 to $5 \mathrm{~W} \mathrm{~m}^{-2}$ decade $^{-1}$ (1960-1990 period), corresponding to a decline of 4 to $9 \%$. A partial recovery ("global brightening") has been registered more recently (1986-2000) at many locations $\left(2.2 \mathrm{~W} \mathrm{~m}^{-2}\right.$ decade $^{-1}$, corresponding to a rise of $\left.2 \%\right)$. According to Wild (2009), changes in solar radiation can be due to (1) changes in cloud cover and optical properties, (2) changes in water vapor, and (3) changes in the mass and optical properties of aerosols. However, sensitivity studies indicate that considerable changes in water vapor would be necessary to explain the observed solar radiation trends, while changes in cloud and aerosol characteristics are the dominant factors (Wild, 1997). Since early 1990s, reduced emissions have been registered in Asia, with a resulting decline of aerosol concentrations (Streets et al., 2009). This trend reversal in aerosol levels fits the general picture of a widespread 
transition from dimming to brightening (Ramanathan et al., 2005). Furthermore, the weakness of the monsoon could correspond to minor cloud coverage; both factors are favorable for hypotheses of an increase in solar radiation in this region. Furthermore, the aerosol-cloud interactions cause an amplification of dimming and brightening trends in pristine environments (Kaufman et al., 2005; Wild, 2009). The average solar radiation at the $5050 \mathrm{~m}$ elevation is $12.4 \mathrm{MJ} \mathrm{m}^{-2} \mathrm{~d}^{-1}$ $\left(143.5 \mathrm{~W} \mathrm{~m}^{-2}\right)$ (Tartari et al., 2002). The increase of nearly $15 \%\left(1.8 \mathrm{MJ} \mathrm{m}^{-2} \mathrm{~d}^{-1}\right.$ or $\left.19.7 \mathrm{~W} \mathrm{~m}^{-2}\right)$ of solar radiation, according to the ELA-climate model, is large if compared with the $2 \%$ of global rise reported for recent years, but it cannot be excluded, according to Kaufman et al. (2005) and Wild (2009), that the aerosol-cloud interactions cause an amplification of dimming and brightening trends in pristine environments.

\subsection{Acceleration of the recession process}

We observed clear signs of glacier changes since the 1960 s on the south slope of the Mt. Everest region. All of the variables analyzed showed a continuing deglaciation trend. The phenomenon appears to be accelerated in recent decades, particularly with regards to the loss of surface area and the upward shift of the SLA. Based on this evidence, we decided to deepen the analysis to shed light on what may be the boundary conditions favoring the process and the possible drivers of change. Many authors (Salerno et al., 2008; Yao et al., 2012) have already shown that the glacier area loss rate is related to size of the glacier. Therefore, we divided the glaciers into three-dimensional classes $\left(<2.5 \mathrm{~km}^{2}\right.$; $2.5-10 \mathrm{~km}^{2} ;>10 \mathrm{~km}^{2}$ ) that were defined to contain a similar number of glaciers in each class. For each variable, we analyzed the differences in cumulative changes in the overall period (1962-2011) (Fig. 7a, c, e) and the differences in the annual rate of change between two periods (1962-1992 and 1992-2011) (Fig. 7b, d, f).

In Fig. 7a, we observe that the cumulative terminus retreat, in the overall 1962-2011 period, is $55 \mathrm{~m}$ (median) for glaciers $<2.5 \mathrm{~km}^{2}$ and $433 \mathrm{~m}$ (median) for glaciers $>10 \mathrm{~km}^{2}$. If we compare these values with the length of the ablation area of the glacier we would get a percentage of terminus retreat double for the largest glaciers $(2.3 \%, 4.3 \%$, respectively for the 1962-2011 period). In order to understand this divergent glacier behavior we need to deepen the possible linkage between $\Delta$ Term and the other variables of change. As discussed earlier, the terminus retreat of each glacier is strongly related to the increase of debris coverage $(r=0.87, p<0.001$ for $\Delta$ DebrisCov vs $\Delta$ Term/length of the ablation zone). Although we did not find any significant correlation with the glacier elevation, the termini retreat is related to the $\triangle$ SLA $(r=0.67, p<0.01$ for $\triangle$ SLA vs $\Delta$ Term/length of the ablation zone), that means more negative glacier mass balances induce an increasing of debris coverage $(r=0.79, p<0.01$ for $\Delta$ SLA vs $\Delta$ DebrisCov) (e.g., Chiarle et al., 2007; Rickenmann and Zimmermann, 1993) and a lower glacier retreat. As discussed below, we observed higher $\triangle$ SLA for larger glaciers $(r=0.60, p<0.01)$ and thus, we can consider clarified the reason because larger glaciers experienced double terminus retreats.

We have already discussed that these glaciers, regardless of size, did not show a significant increase in the annual retreat rate. In Fig. 7b, we note that the annual retreat rate is increasing for all classes and especially for the glaciers of greater size, but these differences are not significant even considering the glaciers' size $(p=0.41, p=0.52, p=0.13$, from small to large, respectively), which means that each class contains a significant number of glaciers that are not currently accelerating the process.

Regarding the glacier surface area losses, we showed a general decrease of $13.0 \pm 3.1 \%$ between 1962 and 2011 . In Fig. 7c, we can observe that the percentage of area loss is $9.0 \pm 3.3 \%$ for the glaciers $>10 \mathrm{~km}^{2}$, but that this percentage rises to $36.0 \pm 4.8 \%$ for the glaciers $<2.5 \mathrm{~km}^{2}$. For the glaciers $<1 \mathrm{~km}^{2}$, this percentage rises to $42.0 \pm 5.8 \%$. Comparing the annual rate of area loss, we note an interesting change (Fig. 7d): the rate is increasing in the 19922011 period from the previous period for all classes, but it is especially increasing for glaciers of larger size. By testing the significance of these differences, only the rate of glaciers $>10 \mathrm{~km}^{2}$ were significant between two periods. The $p$ values were $0.13,0.80$, and 0.03 , from small to large, respectively, compared to the overall significant area loss, as highlighted above.

A similar picture emerges if we consider the changes in the SLA (Fig. 7f). Significant differences were found between two periods only for glaciers $>10 \mathrm{~km}^{2}(p=0.15, p=0.25$, and $p=0.03$, from small to large, respectively) compared to a significant overall shift in SLA, as highlighted above. It is also interesting to note (Fig. 7e) that these glaciers presented median upward shifts equal to more than $220 \mathrm{~m}$, while smaller glaciers showed increases of $119 \mathrm{~m}$ (approximately half).

Based on all these evidences, we can say that from the 1960s to today, the glaciers that have undergone the most climate impact are small ones, but it is also true that over the last 2 decades, the condition of larger glaciers has worsened much more. To find the reasons for this differential acceleration, first of all, we have to consider that the glaciers size is significantly correlated with the mean and the minimum (i.e., SLA) elevation of the accumulation zone $(r=0.61$, $p<0.01 ; r=0.54, p<0.01)$, while it is not significantly correlated with the mean as well as the minimum elevation of ablation zone. Therefore, larger glaciers present accumulation zones at higher elevations. Moreover, we found the largest glaciers are mainly south oriented $(r=0.62$, $p<0.05)$. In this regards, Salerno et al. (2008) observed that in the period ranging from the 1950 s to 1992 , larger glaciers decreased less in size and that some of them were on the rise. This divergent behavior was explained by considering the 
increase of precipitation registered in those years that favored the south-oriented glaciers (along the preferential monsoon axis) and those that were located at higher elevations, thus less subjected to the temperature warming effects. This interpretation agrees with Fowler and Archer (2006), who examined the upper Indus Basin and found that the temperature change could play a pronounced effect on glaciers located at lower altitudes, while the precipitation change could be the main driver of mass balance and $\triangle$ SLA of glaciers located at higher altitudes, which have surface temperatures lower than the melting point. The veracity of this statement must match the present study because the glaciers of the south slopes of Mt. Everest are among the highest glaciers in the world, as mentioned above, and these altitudes have preserved these glaciers, more than the other parts of the Himalaya, from excessive melting. Therefore, the double upward shift of SLA of the largest glaciers (i.e., south-oriented and with higher altitude accumulation zone) compared to the smallest and the acceleration observed for these glaciers in term of shifts in SLA and surface area loss indicate the weakening of the Asian monsoon, which has led to a loss of $173 \mathrm{~mm}$ of precipitation in this region for the 1979-2010 period (e.g., Yao et al., 2012; Palazzi et al., 2013). Following the same reasoning for the acceleration observed from the 1990s, this loss could be mainly due to a minor accumulation that involved more large glaciers than an increase in melting at these elevations. Wagnon et al. (2013) recently arrived at the same conclusion. In fact, analyzing two glaciers in the Dudh Koshi Basin, they justify the observed negative mass balances mainly as the consequence of weakening of the Asian monsoon.

\section{Conclusions}

We have provided a comprehensive picture of the glacier changes to the south of Mt. Everest since the early 1960s. We considered five intermediate periods and analyzed available optical satellite imagery. An overall reduction in glacier area of $13.0 \pm 3.1 \%$ was observed, which was accompanied by an upward shift of the snow-line altitude (SLA) of $182 \pm 22 \mathrm{~m}$, a terminus retreat of $403 \pm 9 \mathrm{~m}$, and an increase of the debris coverage of $17.6 \pm 3.1 \%$. Over the last 20 years, we noted an acceleration of the surface area loss and SLA. However, the increased recession velocity has only significantly affected the glaciers of the largest sizes. These glaciers present median upward shifts equal to more than $220 \mathrm{~m}$, while the smaller ones have increases of about half of that. Temperature variations, despite being the primary cause eliciting glacier response, cannot alone account for why these glaciers, located at higher altitudes, reordered such a high upward shift of SLA and why their annual rate of area loss increased much more than that of the other glaciers. We propose that in the case of larger glaciers that have accelerated area loss processes, the effects of the current weakening of the Asian monsoon were added to the effects of increasing temperatures because the glaciers' orientation is aligned with the prevailing precipitation, which makes these glaciers more sensitive to variations in precipitation than to variations in temperatures.

Moreover, we noted that the shrinkage of these glaciers is lower than in the entire Himalayan range. Their location at higher elevations have reduced the warming impact, but have not been able to exclude these glaciers from a relentlessly continuous and slow recession process over the past 50 years.

\section{The Supplement related to this article is available online at doi:10.5194/tc-8-1297-2014-supplement.}

Acknowledgements. This work was supported by the Ministry of Education, Universities and Research (MIUR) through Ev-K2CNR/SHARE and CNR-DTA/NEXTDATA projects within the framework of the Ev-K2-CNR and Nepal Academy of Science and Technology (NAST) collaboration in Nepal. S. Thakuri is recipient of the Intergovernmental Panel on Climate Change (IPCC) Scholarship Award under the collaboration between the IPCC Scholarship Programme and the Prince Albert II of Monaco Foundation's Young Researcher Scholarships Initiative. T. Bolch acknowledges funding through Deutsche Forschungsgemeinschaft (DFG).

Edited by: E. Larour

\section{References}

Ageta, Y. and Fujita, K.: Characteristics of mass balance of summeraccumulation type glaciers in the Himalayas and Tibetan Plateau, Z. Gletscherkd, Glazialgeol., 32, 61-65, 1996.

Amatya, L. K., Cuccillato, E., Haack, B., Shadie, P., Sattar, N., Bajracharya, B., Shrestha, B., Caroli, P., Panzeri, D., Basani, M., Schommer, B., Flury, B., Salerno, F., and Manfredi, E. C.: Improving Communication for Management of Social-ecological Systems in High Mountain Areas: Development of Methodologies and Tools - The HKKH Partnership Project, Mt. Res. Dev., 30, 69-79, 2010.

Asahi, K.: Equilibrium-line altitudes of the present and Last Glacial Maximum in the eastern Nepal Himalayas and their implications for SW monsoon climate, Quatern. Int., 212, 26-34, 2010.

Bagla, P.: No sign yet of Himalayan meltdown, Indian report finds, Science, 326, 924-925, 2009.

Bajracharya, B., Pradhan S., Shrestha B., and Salerno F.: An Integrated Decision Support Toolbox (DST) for the Management of Mountain Protected Areas. Mt. Res. Dev., 30, 94-102, 2010.

Bajracharya, S. R. and Mool, P.: Glaciers, glacial lakes and glacial lake outburst floods in the Mount Everest region, Nepal, Ann. Glaciol., 50, 81-86, 2009.

Basnett, S. Kulkarni, A., and Bolch, T.: The influence of debris cover and glacial lakes on the recession of glaciers in Sikkim Himalaya, India, J. Glaciol., 59, 1035-1046, 2013.

Benn, D. I., Benn, T., Hands, K., Gulley, J., Luckman, A., Nicholson, L. I., Quincey, D., Thompson, S., Toumi, R., and Wiseman, 
S.: Response of debris-covered glaciers in the Mount Everest region to recent warming, and implications for outburst flood hazards, Earth-Sci. Rev., 114, 156-174, 2012.

Bhambri, R. and Bolch, T.: Glacier mapping: a review with special reference to the Indian Himalayas. Prog. Phys. Geog., 33, 672704, 2009.

Bhambri, R., Bolch, T., Chaujar, R. K., and Kulshreshtha, S. C.: Glacier changes in the Garhwal Himalaya, India, from 1968 to 2006 based on remote sensing, J. Glaciol., 57, 543-556, 2011.

Bhambri, R., Bolch, T., and Chaujar, R. K.: Frontal recession of Gangotri glacier, Garhwal Himalayas, from 1965 to 2006, measured through high-resolution remote sensing data, Curr. Sci., 102, 489-494, 2012.

Bolch, T., Buchroithner, M., Pieczonka, T., and Kunert, A.: Planimetric and volumetric glacier changes in the Khumbu Himalaya since 1962 using Corona, Landsat TM and ASTER data, J. Glaciol., 54, 592-600, 2008a.

Bolch, T., Buchroithner, M. F., Peters, J., Baessler, M., and Bajracharya, S.: Identification of glacier motion and potentially dangerous glacial lakes in the Mt. Everest region/Nepal using spaceborne imagery, Nat. Hazards Earth Syst. Sci., 8, 13291340, 2008b,

http://www.nat-hazards-earth-syst-sci.net/8/1329/2008/.

Bolch, T., Pieczonka, T., and Benn, D. I.: Multi-decadal mass loss of glaciers in the Everest area (Nepal Himalaya) derived from stereo imagery, The Cryosphere, 5, 349-358, doi:10.5194/tc-5349-2011, 2011.

Bolch, T., Kulkarni, A., Kääb, A., Huggel, C., Paul, F., Cogley, J. G., Frey, H., Kargel, J. S., Fujita, K., Scheel, M., Bajracharya, S., and Stoffel, M.: The state and fate of Himalayan glaciers, Science, 336, 310-314, 2012

Brahmbhatt, R. M., Bahuguna, I. M., Rathore, B. P., Kulkarni, A. V., Nainwal, H. C., Shah, R. D., and Ajai: A comparative study of deglaciation in two neighbouring basins (Warwan and Bhut) of Western Himalaya, Curr. Sci., 103, 298-304, 2012.

Byers, A. C.: Landscape change in Sagarmatha (Mt. Everest) National Park, Khumbu, Nepal, Himalayan Res. Bull., XVII, 31-41, 1997.

Chen, J., Zhu, X., Vogelmann, J. E., Gao, F., and Jin, S.: A simple and effective method for filling gaps in Landsat ETM+ SLC-off images, Remote Sens. Environ., 115, 1053-1064, 2011.

Chiarle, M., Lannotti, S., Mortara, G., and Deline, P.: Recent debris flow occurrences associated with glaciers in the Alps, Glob. Planet Change, 56, 123-136, 2007.

Chinn, T. J., Heydenrych, C., and Salinger, M. J.: Use of the ELA as a practical method of monitoring glacier response to climate in New Zealand's Southern Alps, J. Glaciol., 51, 85-95, 2005.

Cogley, J. G., Kargel, J. S., Kaser, G., and Van der Veen, C. J.: Tracking the source of glacier misinformation, Science, 327, p. 522, 2010.

Cook, E. R., Krusic, P. J., and Jones, P. D.: Dendroclimatic signals in long tree-ring chronologies from the Himalayas of Nepal, Int. J. Climatol., 23, 707-732, 2003.

Dette, H. and Neumeyer, N.: Nonparametric Analysis of Covariance, Ann. Stat., 29, 1361-1400. 2001,

Diodato, N., Bellocchi, G., and Tartari, G.: How do Himalayan areas respond to global warming?, Int. J. Climatol., 32, 975-982, 2012.

Fowler, H. J. and Archer, D. R.: Conflicting Signals of Climatic Change in the Upper Indus Basin, J. Clim., 19, 4276-4293, 2006.
Frey, H., Paul, F., and Strozzi, T.: Compilation of a glacier inventory for the western Himalayas from satellite data: methods, challenges and results, Remote Sens. Environ., 124, 832-843, 2012.

Fujita, K. and Nuimura, T.: Spatially heterogeneous wastage of Himalayan glaciers, Proc. Natl. Acad. Sci. USA, 108, 1401114014, 2011.

Fujita, K., Thompson, L. G., Ageta, Y., Yasunari, T., Kajikawa, Y., Sakai, A., and Takeuchi, N.: Thirty-year history of glacier melting in the Nepal Himalayas, J. Geophys. Res., 111, D03109, doi:10.1029/2005JD005894, 2006.

Gardelle, J., Arnaud, Y., and Berthier, E.: Contrasted evolution of glacial lakes along the Hindu Kush Himalaya mountain range between 1990 and 2009, Global Planet. Change, 75, 47-55, 2011.

Gardelle, J., Berthier, E., Arnaud, Y., and Kääb, A.: Region-wide glacier mass balances over the Pamir-Karakoram-Himalaya during 1999-2011, The Cryosphere, 7, 1263-1286, doi:10.5194/tc7-1263-2013, 2013.

Grosse, G., Schirrmeister, L., Kunitsky, V. V., and Hubberten, H. W.: The use of CORONA images in remote sensing of periglacial geomorphology: an illustration from the NE Siberian coast, Permafrost Periglac., 16, 163-172, 2005.

Hall, D. K., Bayr, K. J., Schoner, W., Bindschadler, R. A., and Chien, J. Y. L.: Consideration of the errors inherent in mapping historical glacier positions in Austria from the ground and space (1893-2001), Remote Sens. Environ., 86, 566-577, 2003.

Hambrey, M. and Alean, J.: Glaciers. 2nd ed., Cambridge University Press, 376 pp., 2004.

Hess, H.: Die Gletscher, Braunschweig, 406 pp., 1904.

Hewitt, K.: Tributary glacier surges: an exceptional concentration at Panmah Glacier, Karakoram Himalaya, J. Glaciol., 53, 181-188, 2007.

Hoelzle, M., Chinn, T., Stumm, D., Paul, F., Zemp, M., and Haeberli, W.: The application of inventory data for estimating past climate change effects on mountain glaciers: a comparison between the European Alps and the Southern Alps of New Zealand, Global Planet. Change, 56, 69-82, 2007.

Hooke, R. L.: Principles of Glacier Mechanics, Cambridge University Press, 429 pp., 2005.

Ichiyanagi, K., Yamanaka, M. D., Muraji, Y., and Vaidya, B. K.: Precipitation in Nepal between 1987 and 1996, Int. J. Climatol., 27, 1753-1762, 2007.

Jones, P. D. and Moberg, A.: Hemispheric and large-scale surface air temperature variations: an extensive revision and an update to 2001, J. Climate, 16, 206-223, 2003.

Kääb, A., Berthier, E., Nuth, C., Gardelle, J., and Arnaud, Y.: Contrasting patterns of early twenty-first-century glacier mass change in the Himalayas, Nature, 488, 495-498, 2012.

Karpilo, R. D. J.: Glacier monitoring techniques, in: Geological Monitoring, edited by: Young, R. and Norby, L., The Geological Society of America, Boulder, Colorado, 141-162, 2009.

Kattel, D. B. and Yao, T.: Recent temperature trends at mountain stations on the southern slope of the Central Himalayas, J. Earth Syst. Sci., 122, 215-227, 2013.

Kaufman, Y. J., Koren, I., Remer, L. A., Tanre, D., Ginoux, P., and Fan, S.: Dust transport and deposition observed from the Terra-moderate Resolution Imaging Spectroradiometer (MODIS) spacecraft over the Atlantic Ocean, J. Geophys. Res. Atmos., 110, D10S12, doi:10.1029/2003JD004436, 2005. 
Kayastha, R. B. and Harrison, S. P.: Changes of the equilibriumline altitude since the little ice age in the Nepalese Himalaya, Ann. Glaciol., 48, 93-99, 2008.

Kerschner, H.: Statistical modelling of equilibrium-line altitudes of Hintereisferner, central Alps, Austria, 1859-present, Ann. Glaciol., 24, 111-115, 1997.

Koblet, T., Gartner-Roer, I., Zemp, M., Jansson, P., Thee, P., Haeberli, W., and Holmlund, P.: Reanalysis of multi-temporal aerial images of Storglaciaren, Sweden (1959-99) - Part 1: Determination of length, area, and volume changes, The Cryosphere, 4 : 333-343, doi:10.5194/tc-4-333-2010, 2010.

Kresse, W. and Danko, D. M.: Springer Handbook of Geographic Information, Springer Verlag, 1120 pp., 2011.

Kuhn, M.: Climate and glaciers. Sea level, ice and climatic change, in: Proceedings of the Canberra Symposium, December 1979, edited by: Allison, I., December 1979, IASH Publ. 131, 3-20, 1981.

Kulkarni, A. V., Rathore, B. P., Singh, S. K., and Bahuguna, I. M.: Understanding changes in the Himalayan cryosphere using remote sensing techniques, Int. J. Remote Sens., 32, 601-615, 2011.

Lami, A., Marchetto, A., Musazzi, S., Salerno, F., Tartari, G., Guilizzoni, P., Rogora, M., and Tartari, G. A.: Chemical and biological response of two small lakes in the Khumbu Valley, Himalayas (Nepal) to short-term variability and climatic change as detected by long-term monitoring and paleolimnological methods, Hydrobiologia, 648, 189-205, 2010.

Leonard, K. C. and Fountain, A. G.: Map-based methods for estimating glacier equilibrium-line altitudes, J. Glaciol., 49, 329336, 2003

Liu, X. and Chen, B.: Climatic warming in the Tibetan Plateau during recent decades, Int. J. Climatol., 20, 1729-1742, 2000.

Lorenz, H.: Integration of Corona and Landsat Thematic Mapper data for bedrock geological studies in the high Arctic, Int. J. Remote Sens., 25, 5143-5162, 2004.

Manfredi, E. C., Flury, B., Viviano, G., Thakuri, S., Khanal, S. N., Jha P. K., Maskey, R. K., Kayastha, R. B., Kafle, K. R., Bhochhibhoya, S. B., Ghimire, N. P., Shrestha, B. B., Gyanendra, C., Giannino, F., Carteni, F., Mazzoleni, S., and Salerno, F.: Solid Waste and Water Quality Management Models for Sagarmatha National Park and Buffer Zone, Nepal: Implementation of a Participatory Modeling Framework, Mt. Res. Dev., 30, 127 142,2010

McFadden, E. M., Ramage, J., and Rodbell, D. T.: Landsat TM and ETM+ derived snowline altitudes in the Cordillera Huayhuash and Cordillera Raura, Peru, 1986-2005, The Cryosphere, 5, 419430, doi:10.5194/tc-5-419-2011, 2011.

Mernild, S., Pelto, M., Malmros, J., Yde, J., Knudsen, N., and Hanna, E.: Identification of snow ablation rate, ELA, AAR and net mass balance using transient snowline variations on two Arctic glaciers, J. Glaciol., 59, 649-659, doi:10.3189/2013JoG12J221, 2013.

Mool, P. K., Bajracharya, S. R., and Joshi, S. P.: Inventory of Glaciers, Glacial Lakes and Glacial Lake Outburst Floods, Monitoring and Early Warning Systems in the Hindu Kush-Himalaya Region, ICIMOD, Nepal, 2001.

Naidu, C. V., Durgalakshmi, K., Muni Krishna, K., Ramalingeswara, S., Satyanarayan, G. C., Lakshminarayana, P., and Rao, L. M.: Is summer monsoon rainfall decreasing over India in the global warming era? J. Geophys. Res.-Atmos., 114, D24108, doi:10.1029/2008JD011288, 2009.

Nakawo, M., Yabuki, H., and Sakai, A.: Characteristics of Khumbu Glacier, Nepal Himalaya: recent change in the debris-covered area, Ann. Glaciol., 28, 118-122, 1999.

Nie, Y., Zhang, Y., Liu, L., and Zhang, J.: Glacial change in the vicinity of Mt. Qomolangma (Everest), central high Himalayas since 1976, J. Geogr. Sci., 20, 667-686, 2010.

Nuimura, T., Fujita, K., Yamaguchi, S., and Sharma, R. R.: Elevation changes of glaciers revealed by multitemporal digital elevation models calibrated by GPS survey in the Khumbu region, Nepal Himalaya, 1992-2008, J. Glaciol., 58, 648-656, 2012.

Oerlemans, J.: Glaciers and Climate Change, edited by: Oerlemans, J., A. A. Balkema Publishers, Rotterdam, 160 pp., 2001.

Ouimet, W., Whipple, K., and Granger, D.: Beyond threshold hillslopes: Channel adjustment to base-level fall in tectonically active mountain ranges, Geology, 37, 579-582, 2009.

Owen, L. A. and Benn, D. I.: Equilibrium-line altitudes of the Last Glacial Maximum for the Himalaya and Tibet: an assessment and evaluation of results, Quatern. Int., 138-139, 55-78, 2005.

Palazzi, E., von Hardenberg, J., and Provenzale, A.: Precipitation in the Hindu-Kush Karakoram Himalaya: observations and future scenarios, J. Geophys. Res.-Atmos. 118, 85-100, 2013.

Parkinson, C. L., Ward, A., and King, M. D.: Earth Science Reference Handbook, A Guide to NASA's Earth Science Program and Earth Observing Satellite Missions: National Aeronautics and Space Administration, 2006.

Paul, F., Barrand, N., Berthier, E., Bolch, T., Casey, K., Frey, H., Joshi, S. P., Konovalov, V., Le Bris, R., Molg, N., Nosenko, G., Nuth, C., Pope, A., Racoviteanu, A., Rastner, P., Raup, B., Scharrer, K., Steffen, S., and Winsvold, S.: On the accuracy of glacier outlines derived from remote sensing data. Ann. Glaciol., 54, 171-182, 2013.

Paul, F., Barry, R. G., Cogley, J. G., Frey, H., Haeberli, W., Ohmura, A., Ommanney, C. S. L., Raup, B., Rivera, A., and Zemp, M.: Recommendations for the compilation of glacier inventory data from digital sources, Ann. Glaciol., 50, 119-126, 2009.

Paul, F., Huggel, C., and Kääb, A.: Combining satellite multispectral image data and a digital elevation model for mapping debriscovered glaciers, Remote Sens. Environ., 89, 510-518, 2004.

Pelto, M.: Utility of late summer transient snowline migration rate on Taku Glacier, Alaska, The Cryosphere, 5, 1127-1133, doi:10.5194/tc-5-1127-2011, 2011.

Pelto, M., Kavanaugh, J., and McNeil, C.: Juneau Ice field Mass Balance Program 1946-2011, Earth Syst. Sci. Data, 5, 319-330, doi:10.5194/essd-5-319-2013, 2013.

Pieczonka, T., Bolch, T., Wei, J., and Liu, S.: Heterogeneous mass loss of glaciers in the Aksu-Tarim Catchment (Central Tien Shan) revealed by 1976 KH-9 Hexagon and 2009 SPOT-5 stereo imagery, Remote Sens. Environ., 130, 233-244, 2013.

Quincey, D. J., Luckman, A., and Benn, D.: Quantification of Everest region glacier velocities between 1992 and 2002, using satellite radar interferometry and feature tracking, J. Glaciol., 55, 596-606, 2009.

Rabatel, A., Letréguilly, A., Dedieu, J. P., and Eckert, N.: Changes in glacier equilibrium-line altitude in the western Alps from 1984 to 2010: evaluation by remote sensing and modeling of the morpho-topographic and climate controls, The Cryosphere, 7, 1455-1471, doi:10.5194/tc-7-1455-2013, 2013. 
Rabatel, A., Bermejo, A., Loarte, E., Soruco, A., Gomez, J., Leonardini, G., Vincent, C., and Sicart, J. E.: Can the snowline be used as an indicator of the equilibrium line and mass balance for glaciers in the outer tropics?, J. Glaciol., 58, 1027-1036, 2012.

Rabatel, A., Dedieu, J. P., and Vincent, C.: Using remote-sensing data to determine equilibrium-line altitude and mass-balance time series: validation on three French glaciers, 1994-2002, J. Glaciol., 51, 539-546, 2005.

Racoviteanu, A., Williams, M., and Barry, R.: Optical Remote Sensing of Glacier Characteristics: A Review with Focus on the Himalaya, Sensors, 8, 3355-3383, 2008.

Ramanathan, V., Chung, C., Kim, D., Bettge, T., Buja, L., Kiehl, J. T., Washington, W. M., Fu, Q., Sikka, D. R., and Wild, M.: Atmospheric brown clouds: impacts on south Asian climate and hydrological cycle, Proc. Natl. Acad. Sci. USA, 102, 5326-5333, 2005.

Rao, Y. P.: Southwest Monsoon, India Meteorological Department. Meteorological Monograph, New Delhi, 366 pp., 1976.

Rastner, P., Bolch, T., Notarnicola, C., and Paul, F.: A comparison of pixel- and object based glacier classification with optical satellite images. IEEE J. Sel. Topics Appl. Earth Observ., doi:10.1109/JSTARS.2013.2274668, 2013.

Rickenmann, D. and Zimmermann, M.: The 1987 debris flows in Switzerland: documentation and analysis, Geomorphology, 8, 175-189, 1993.

Rodriguez-Galiano, V. F., Pardo-Iguzquiza, E., Chica-Olmo, M., Mateos, J., Rigol-Sanchez, J. P., and Vega, M.: A comparative assessment of different methods for Landsat 7/ETM+ pansharpening, Int. J. Remote Sens., 33, 6574-6599, 2012.

Rosenholm, D. and Akerman, D.: Digital orthophotos from IRS production and utilization, in: IAPRS, edited by: Fritsch, D., Englich, M. and Sester, M., ISPRS Commission IV Symposium on GIS - Between Visions and Applications, Stuttgart, Germany, 32, 501-505, 1998.

Salerno, F., Buraschi, E., Bruccoleri, G., Tartari, G., and Smiraglia C.: Glacier surface-area changes in Sagarmatha National Park, Nepal, in the second half of the 20th century, by comparison of historical maps, J. Glaciol., 54, 738-752, 2008.

Salerno, F., Viviano, G., Thakuri, S., Flury, B., Maskey, R. K., Khanal, S. N., Bhuju, D., Carrer, M., Bhochhibhoya, S., Melis, M. T., Giannino, F., Staiano, A., Carteni, F., Mazzoleni, S., Cogo, A., Sapkota, A., Shrestha, S., Pandey, R. K., and Manfredi, E. C.: Energy, forest, and indoor air pollution models for Sagarmatha National Park and Buffer zone, Nepal: implementation of a participatory modeling framework, Mt. Res. Dev., 30, 113-126, 2010a.

Salerno, F., Cuccillato, E., Caroli, P., Bajracharya, B., Manfredi, E. C., Viviano, G., Thakuri, S., Flury, B., Basani, M., Giannino, F., and Panzeri, D.: Experience with a hard and soft participatory modeling framework for social ecological system management in Mount Everest (Nepal) and K2 (Pakistan) protected areas, Mt. Res. Dev., 30, 80-93, 2010b.

Salerno, F., Thakuri, S., D’Agata, C., Smiraglia, C., Manfredi, E. C., Viviano, G., and Tartari, G.: Glacial lake distribution in the Mount Everest region: Uncertainty of measurement and conditions of formation, Global Planet. Change, 92-93, 30-39, 2012.

Salerno, F., Viviano, G., Mangredi, E. C., Caroli, P., Thakuri, S., and Tartari, G.: Multiple Carrying Capacities from a management- oriented perspective to operationalize sustainable tourism in protected area, J. Environ. Manag., 128, 116-125, 2013.

Scherler, D., Bookhagen, B., and Strecker, M. R.: Spatially variable response of Himalayan glaciers to climate change affected by debris cover, Nat. Geosci., 4, 156-159, 2011.

Schneider, E.: Begleitworte zur Karte Khumbu Himal und zur Namensgebung, in: Khumbu Himal, edited by: Hellmich, W., Universitasverlag Wagner, Innsbruck, (Ergebnisse des Forschungsunternehmens Nepal Himalaya Band 1, Lieferung 5.), 430-446, 1967.

Shapiro, S. S. and Wilk, M. B.: An analysis of variance test for normality (complete samples), Biometrika, 52, 591-611, 1965.

Shangguan, D., Liu, S., Ding, Y., Wu, L., Deng, W., Guo, W., Wang, Y., Xu, J., Yao, X., Guo, Z., and Zhu, W.: Glacier changes in the Koshi River basin, central Himalaya, from 1976 to 2009, derived from remote-sensing imagery, Ann. Glaciol., 55, 61-68, 2014.

Sharma, K. P., Moore, B., and Vorosmarty, C. J.: Anthropogenic, climatic, and hydrologic trends in the Kosi basin, Himalaya, Clim. Change, 47, 141-165, 2000.

Streets, D. G., Yan, F., Chin, M., Diehl, T., Mahowald, N., Schultz, M., Wild, M., Wu, Y., and Yu, C.: Anthropogenic and natural contributions to regional trends in aerosol optical depth, 1980-2006, J. Geophys. Res.-Atmos., 114, D00D18, doi:10.1029/2008JD011624, 2009.

Tartari, G., Verza, G., and Bertolami, L.: Meteorological data at the Pyramid Observatory Laboratory (Khumbu Valley, Sagarmatha National Park, Nepal), in: Limnology of high altitude lakes in the Mt. Everest Region (Nepal), edited by: Lami, A. and Giussani, G., Mem. Ist. Ital. Idrobiol., 57, 23-40, 2002.

Tartari, G., Salerno, F., Buraschi, E., Bruccoleri, G., and Smiraglia, C.: Lake surface area variations in the North-Eastern sector of Sagarmatha National Park (Nepal) at the end of the 20th Century by comparison of historical maps, J. Limnol., 67, 139-154, 2008.

Tennant, C., Menounos, B., Ainslie, B., Shea, J., and Jackson, P.: Comparison of modeled and geodetically-derived glacier mass balance for Tiedemann and Klinaklini glaciers, southern Coast Mountains, British Columbia, Canada, Global Planet. Change, 82-83, 74-85, 2012.

Thompson, D., Tootle, G., Asce, M., Kerr, G., Sivanpillai, R., and Pochop, L.: Glacier Variability in the Wind River Range, Wyoming, J. Hydrol. Eng., 16, 798-805, doi:10.1061/(ASCE)HE.1943-5584.0000384, 2011.

Thompson, L. G., Thompson, E. M., Brecher, H., Davis, M., Leon, B., Les, D., Lin, P. N., Mashiotta, T., and Mountain, K.: Abrupt tropical climate change: Past and present, Proc. Natl. Acad. Sci. USA, 103, 10536-10543, 2006.

Wagnon, P., Vincent, C., Arnaud, Y., Berthier, E., Vuillermoz, E., Gruber, S., Ménégoz, M., Gilbert, A., Dumont, M., Shea, J. M., Stumm, D., and Pokhrel, B. K.: Seasonal and annual mass balances of Mera and Pokalde glaciers (Nepal Himalaya) since 2007, The Cryosphere, 7, 1769-1786, doi:10.5194/tc-7-17692013, 2013.

Walford, N.: Practical Statistics for Geographers and Earth Scientists, John Wiley and Sons, 440 pp., 2011.

Wild, M.: The heat balance of the Earth in GCM simulations of present and future climate, Zuercher Geografische Schriften No. 68, Verlag der Fachvereine, Zuerich, 188 pp., 1997.

Wild, M.: Global dimming and brightening: a review, J. Geophys. Res.-Atmos., 114, D00D16, doi:10.1029/2008JD011470, 2009. 
Wild, M., Gilgen, H., Roesch, A., Ohmura, A., Long, C. N., Dutton, E. G., Forgan, B., Kallis, A., Russak, V., and Tsvetkov, A.: From dimming to brightening: decadal changes in solar radiation at Earth's surface, Science, 308, 847-850, 2005.

$\mathrm{Wu}, \mathrm{B} .:$ Weakening of Indian summer monsoon in recent decades, Adv. Atmos. Sci., 22, 21-29, 2005.

Yamada, T.: Glacier lake and its outburst flood in the Nepal Himalaya, Tokyo, Japanese Society of Snow and Ice, Data Center for Glacier Research (Monograph 1), 1998.

Yao, T., Thompson, L., Yang, W., Yu, W., Gao, Y., Guo, X., Yang, X., Duan, K., Zhao, H., Xu, B., Pu, J., Lu, A., Xiang, Y., Kattel, D. B., and Joswiak, D.: Different glacier status with atmospheric circulations in Tibetan Plateau and surroundings, Nat. Clim. Change, 2, 663-667, 2012.
Ye, Q., Kang, S., Chen, F., and Wang, J.: Monitoring glacier variations on Geladandong mountain, central Tibetan Plateau, from 1969 to 2002 using remote-sensing and GIS technologies, J. Glaciol., 52, 537-545, 2006.

Ye, Q., Zhong, Z., Kang, S., Stein, A., Wei, Q., and Liu, J.: Monitoring glacier and supra-glacier lakes from space in Mt. Qomolangma region of the Himalayas on the Tibetan Plateau in China, J. Mt. Sci. China, 6, 211-220, 2009. 